Historic, archived document

Do not assume content reflects current scientific knowledge, policies, or practices. 

$-4$ 



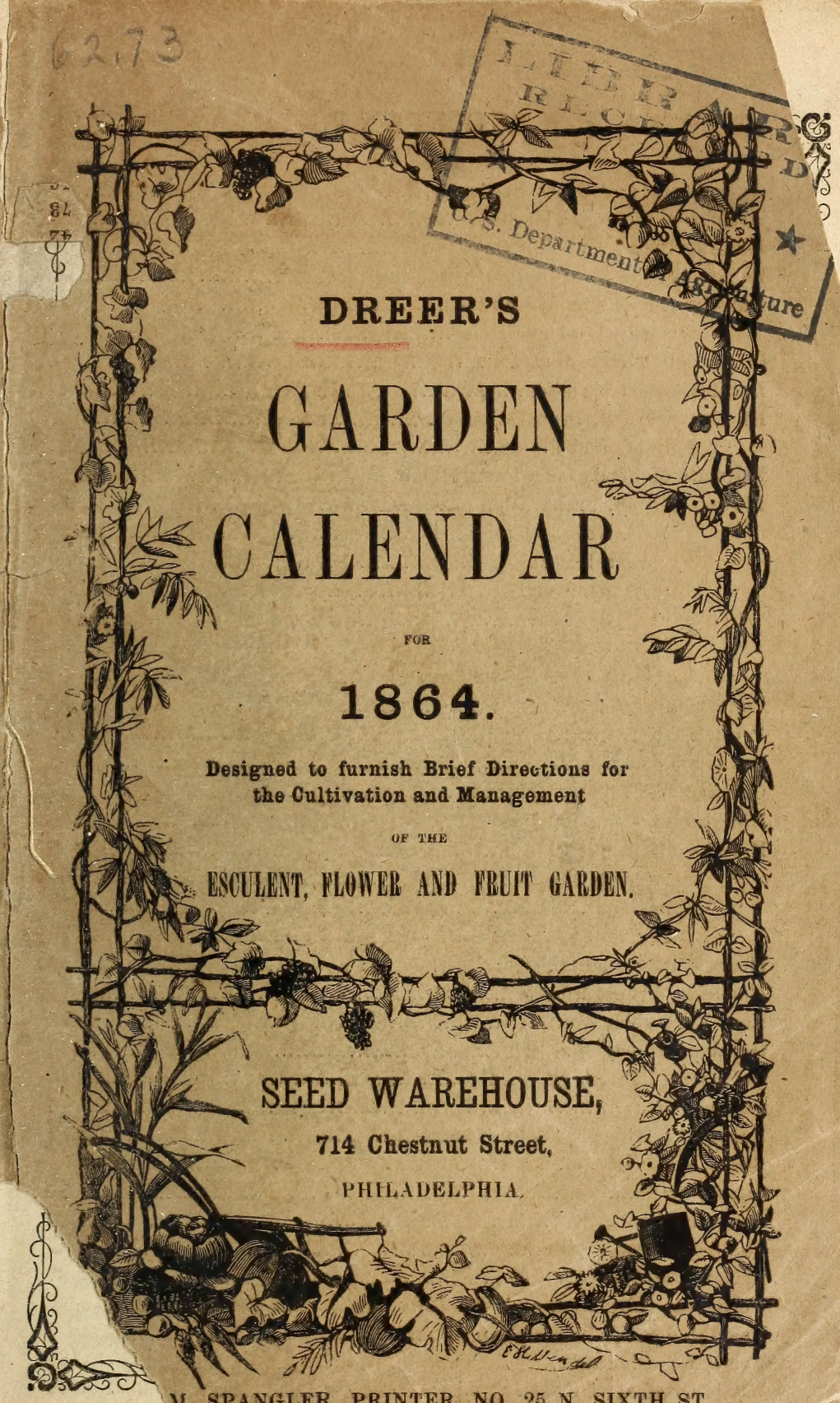

U2. SPANGLER, PRINTER, NO, $25 \mathrm{~N}$. SIXTH ST. 


\section{CONTENTS.}

PAGE.

Agricultural and Grass Seeds....................................... 22

Aromatic and Sweet Herbs......................................... 22

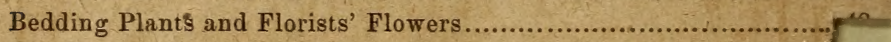

Books on Agriculture and Horticulture..............................

Bulbous Roots, summer flowering.............................. bu

"6 hardy varieties................................... 57

Carnations, Geraniums, \&c......................................... 65

Dahlias, select varieties............................................ 43

Esculent Garden, Preparation of ..................................... 3

6s Roots and Plants................................................. 23

Estimate of Seeds for a Family Garden............................... 5

Flower Garden, Preparation of ................................... 24

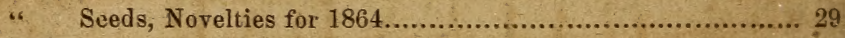

"6 $\quad$ 6 select varieties....................................... 29

" " " general list....................................... 38

" $6 \quad$ German.............................................. 35

" $\quad$ " $:$ for Green-house culture............................. 37

" " . Sowing and Management.............................. 28

Fuchsias, select list............................................. 65

Fruit Garden........................................................ 66

Garden Tools............................................................. 75

Green-house Plants................................................ 61

Hanging Baskets and Vases, Plants for............................ 69

Hardy Herbaceous Plants........................................... हf

"s Flowering Shrubs..............................................6 67

، Vines and Creepers............................................ 67

". Evergreens and Trees.......................................... 70

Hedges, Plants suitable for.......................................... 68

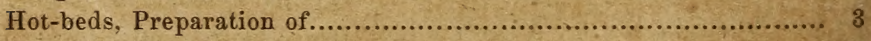

New Vegetables, \&c............................................... 24

Örnameñtal Grasses.................................................... 42

Ornamental Trees and Shrubs.......................................... 70 .

Pampas Grass.......................................................... 48

Raspberry, The Philadelphia.................................... 72

Roses, select lists of, \&c.......................................... 52 to 56

Strawberries........................................................ $\tau_{1}$

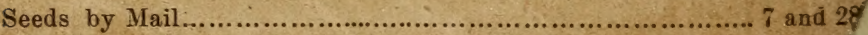

Table of Plants to the Acre

Tobacco Seed and Culture.

Verbenas, cultivation and select lists.

Vegetable seeds, descriptive list..........................................

Window Gardening.

Whale Oil Soap, for destroying Insects. 


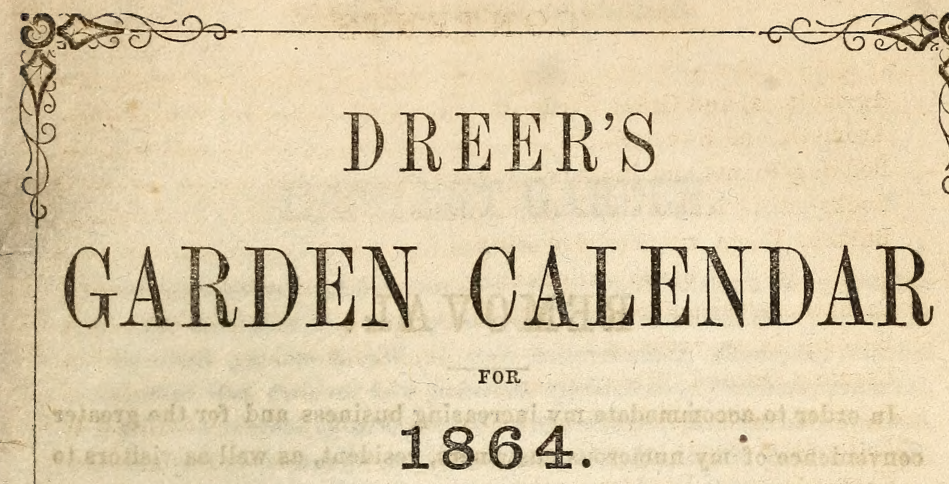

DESIGNED TO FURNISH BRIEF DIRECTIONS

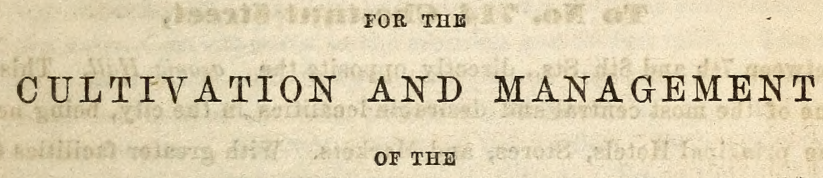

ESCULENT, FLOWER \& FRUIT GARDEN.

ILLUSTRATED WITH WOOD CUTS.

CONTAINING

\section{SELCOT LISTS OP SEEDS, TREES, AND PLANTS,}

\section{HENRY A. DREER,} SEEDSMAN AND FLORIST, No. 714 CHESTNUT STREET, PHOBADESPGOA. 


\section{REMOVAL.}

In order to accommodate my increasing business and for the greater convenience of my numerous customers, resident, as well as visitors to the city I have removed the .

\section{SEED AID HORTICULTURAI WAREHOUSE, To No. \%14 Chestnut Street,}

between 7th and 8th Sts., directly opposite the asonic Hall. This is one of the most central and desirable localities in the city, being near the principal Hotels, Stores, and Markets. With greater facilities for the display of goods, I shall greatly increase my stock of all articles appertaining to the business, and endeavor to supply the increasing wants and taste for Horticulture, now so rapidly developing itself throughout the land, and which, thanks to the present liberal postal arrangements, places it in the power of every one to obtain their supplies, direct, at a trifling cost. [See page 7.]

With a high duty and rate of exchange on all imported articles, the failure of crops at home, and increased cost of every article, I have still endeavored to keep prices as low as possible, hoping by largely increased sales to make up all deficiencies.

In conclusion, I would state that the usual care will be taken in putting up all orders, be they large or small, to give full satisfaction to the purchaser in the quality of the article, as well as in the manner of packing and forwarding.

HENRY A. DREER, 714 Chestnut Street, Philad'a., Pa. 


\section{ESCULENT GARDEN.}

Preparation of the Ground.-To secure a fair return in seasonable crops, for the labor and outlay invested, it is essential that the soil of the Esculent garden should be well under-drained, thoroughly trenched or subsoiled, and enriched by a judicious application of fertilizing material. It is still the current opinion, based on experience, that for all purposes, well-composted barn-yard manure, when available, is the best material. We do not deny but that several of the concentrated manures, now manufactured, are useful and convenient, especially for a succession of crops.

The exposure of a garden, has much to do with the early maturity of the crops; an exposure to the morning sun is desirable. The soil must be in a friable state to secure the prompt regetation of the seeds, and the destruction, or rather prevention of weeds, is one of the most desirable results of frequent stirring of the surface. Soils are susceptible of alteration and improvement in texture; heavy clays can be rendered open and porous, and light sandy soils may be consolidated and rendered more retentive of moisture. For all such details we must refer the amateur to more extensive treatises on these subjects.

Garden Requisites.-There are several aids to the economical management of the garden, which are almost indispensable; one of these is the нот-ВеD frame, for the forwarding of plants for early planting. A frame such as is shown in the cut, may be made of various

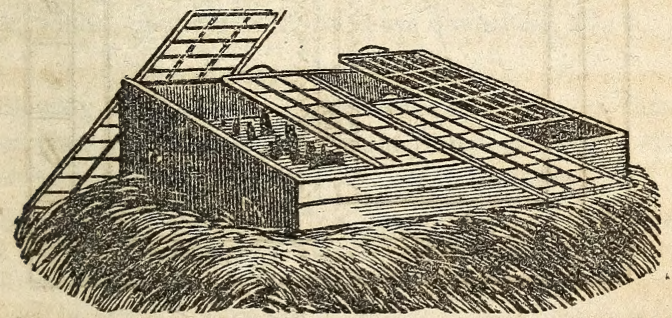

sizes, according to the size of garden, from four sashes upwards. The length of sash is generally seven feet, by three and a half wide, the size of glass six by eight inches, making the entire frame of four sashes, fourteen by seven feet. The frame should have a southern or southeastern exposure, should be made up with fresh horse manure, and a 
few leaves mixed with it; this must be laid in a heap preparatory to being used, and when in a proper state of fermentation, prepared for the reception of the frame. A few inches of rich loamy soil must be spread over the manure, then cover the frame with the sashes and after standing a few days to allow the rank steam and heat to pass off, the seeds can be sown. Where the ground is well drained, a better plan is to dig out a space the size of the frame, from one to two feet deep, according to the season and the heat required, in which the manure is placed, care being taken to pack it in firmly and evenly.

In addition to the Hot-bed frame, mats or shutters will be required to cover the sash during cold days and nights. To work the garden, the necessary implements-spade, fork, shovel, rakes, hoes, trowel, garden line and reel, watering-pot, and wheelbarrow are the most important.

Rotation of Crops. - We are convinced of the importance of a regular rotation of the Esculent crops. To convey the idea briefly, we present a diagram of the garden as laid out to secure this result.

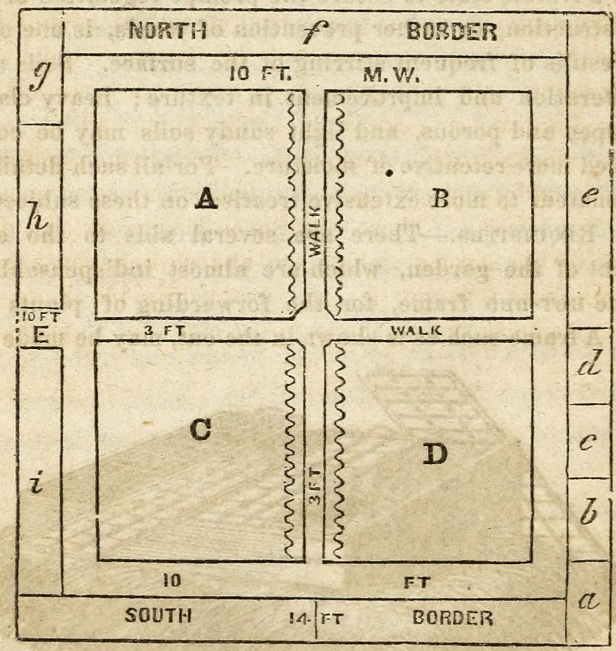

A, B, C \& D. Four compartments in which to plant various erops, alternately. $a$ to $i$. Small compartments round the border for nursing plants, sweet herbs, and setting out permanent beds of Asparagus, Artichoke, Rhubarb, \&c. The border facing South, should be protected on the North side by a close board fence or wall, and will be found useful for sowing early Radish, Lettuce, Beets, and setting out Toma- 
toes, Egg-plants, \&c. The waved line represents a grape trellis; the entrance is at $\mathbf{E}$. This plan may be carried out in a garden of greater or less extent.

\section{Estimate of Seeds calculated to stock a Kitchen-Garden for a family of Ten or Twelve porsons.}

1 oz. Aspargus,

2 qts. Beans, Dwarf or Snap.

1 qt. "6 Horticultural Pole.

1." " " Large Lima.

4 oz. Beet, early and late var.

$\frac{1}{2}$ " Broccoli, Purple Cape.

"Brussels Sprouts.

1 “ Cabbage, two early var.

$\frac{1}{2}$ " " Savoy.

3 " " Red Pickling.

2 " " Jate Drumbead.

4 " Carrot, two varieties.

$\frac{1}{4}$ "Cauliflower, early.

1 "Celery, White and Red.

4 ears Corn, Adams' extra early.

1 qt. " Stowell's Evergreen.

1. " " Large Sugar.

1 oz. Cucumber, early and late.

$\frac{1}{4}$ “ Egg Plant, Large Purple.

$\frac{1}{2}$ " Endive, Curled.

$\frac{3}{2}$ " Kohlrabi, early and late.
2 oz. Lettuce, three varieties.

2 "Melons, assorted.

2 "Okra, Dwarf,

2 "Onion, two varieties.

4 qts. " Sets.

1 oz. Parsley, Extra Curled.

1 " Parsnip, Large Sugar.

2 qts. Peas, Extra Early.

1 " " Tom Thumb.

1. " " " Blue Imperial.

2 " " White Marrowfat.

1 " " Champion of England.

$4 \mathrm{oz}$. Radish, early and late.

2 "Salsafy, or Oyster Plant.

4 " Spinach, Round Savoy.

2 "Squash, assorted.

$\frac{1}{2}$ " Tomato, two varieties.

2 "Turnips, " " "

1 paper each : Pepper, Sage, Sweet Majoram, Thyme, Lavender, Summer Savory.

The above assortment will cost $\$ 10.00$ : one-half of the above quantities, $\$ 5.00$; one-fourth of the above quantities, $\$ 3.00$.

The following table may be useful to the gardener, in showing the number of plants, or trees, that may be raised on an acre of ground, when planted at any of the under-mentioned distances.

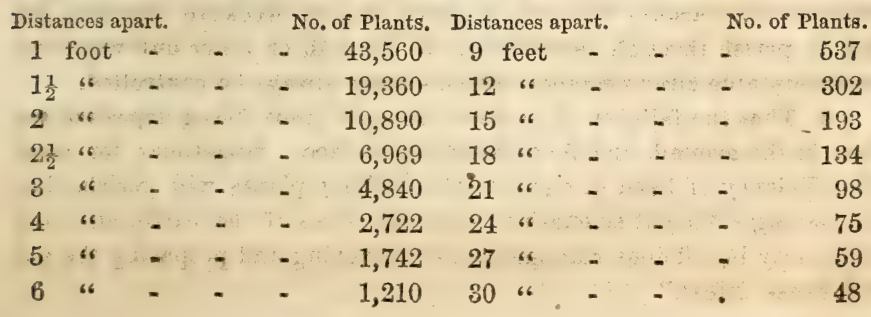




\section{Remarks on the Failure of Seeds.}

"From a conviction that the Seedsman's fair reputation is often unjustly defamed, through the failure of seeds, we would with brevity state some of the causes:

"1. That some cultivators, through ignorance or forgetfulness of the fact, that the products of a garden being natives of various soils and climates, require peculiar management, deposit their seeds in the ground at an improper season. To aid such, we have prepared brief directions, founded on practical experience in the vicinity of Philadelphia, where gardening operations are generally commenced early in March. These directions may, however, be applied to all other parts of the United States, by a minute observance of the difference in temperature.

"Thus, to the North, the directions for March will apply to April; and at the South, to January, February, or whatever season gardening operations may commence in the respective States. The early and most hardy species and varieties should not be planted until the ground can be brought into good condition, as some species of plants that in an advanced stage of growth will stand a hard winter, are often cut off by a very slight frost while young, especially if exposed to the heat of the sun after a frosty night.

"2. That some species of Seeds, such as Beans, Beet, Cabbage, Lettuce, Radish, Salsify, Turnip, \&c., being from their nature, apt to vegetate quickly, are often destroyed while germinating, through variableness of the weather, and some are liable to be devoured by insects in forty-eight hours after they are sown, and before a plant is seen above ground, unless a suitable remedy be applied in due time to annoy the insects.

"3. That some species, as Carrot, Celery, Leek, Onion, Parsley, Parsnip, Spinach, \& ., being naturally of tardy growth, taking (in unfarorable seasons; trom two to three or four weeks to vegetate, are apt to perish through incrustation of the soil, or other untoward and unaccountable circumstances, which cannot always be controlled.

"4. That the failures often occur through Seeds being deposited too deep in the ground, or left too near the surface. Sometimes, for want of sufficiency of Seed in a given spot, solitary plants will perish, they not having sufficient strength to open the pores of the earth, and very frequently injudicious management in manuring and preparing the soil will cause defeat." 
For instructions on these and and other subjects of Gardening, the reader is referred to "Bridgeman's Young Gardener's Assisstant."

Extract. - "Some Gardeners raise Egg Plants, \&c. in the same hot-bed frame with Cabbage, and such other half hardy plants as require air every mild day; by such management one or the other must suffer for want of suitable aliment-heat being the prineipal food of tender plants, and air that of the more hardy species.

"In the sowing of Seeds, remember that in unity there is strength, and that from the germinative parts of a Seed being weak and diminutive, it cannot be expected to perforate through the soil solitary and alone. To insure a fair chance, plant your Seeds moderately thick, and thin out the surplus plants, while young. In planting Seeds in drills, which is the most eligible plan, the size of the Seed and strength of its germ should be considered; large Seeds, producing vigorous roots, require deeper planting than diminutive Seeds, producing delicate roots and slender stalks."

\section{Descriptive List of Esculent Seeds.}

For the convenience of purchasers the Seeds are put up in papers at five and ten cents each. Those quoted at fifty cents per ounce or upwards in not less than ten cent papers.

\section{Seeds by Mrail.}

Under the new Postal law, Seeds, cuttings, bulbs, \&c., can be mailed in packages not exceeding four pounds in weight, at the rate of "two cents for each four ounces or fraction thereof;" this arrangement offers great facilities to persons residing at a distance of procuring reliable and pure Seeds, at a very trifling cost for transportation, as we will mail all orders for Seeds in papers or by the ounce, (Beans, Peas and Corn excepted,) amounting to one dollar or upwards, free of postage charges. When ordered by the pound or quart, eight cents additional per lb. or twelve cents per qt. must be added to the price of the Seeds. A postage stamp must accompany all orders under one dollar.

To insure prompt attention, a remittance must accompany the order. The French, Spanish and German names follow after the English, to each class of regetables.

\section{ARTICHOKE.}

50 cts. per oz.

Artichaut, Fr. Cinauco, Span. Artischocken, Ger.

Large Globe.

Plant the seeds early in April, in rich soil, in drills one inch deep, 
and about twelve inches apart. When one year old, transplant in wellmanured ground, in rows five feet apart, and two feet from plant to plant. Protect during the winter by throwing up ridges of earth, and covering with manure or leaves.

\section{ASPARAGUS.}

10 cts. per oz. 50 cts, per Ib.

Asperge, Fr. Esparrago, Spax. Spargel, Ger.

\section{Large Green. : Lesher's Mammoth.}

Two year old roots, $\$ 1.00$ per hundred.

Sow in March or April, in rich soil. Soak the seed in warm water for 24 hours. Drill it thinly in rows a foot apart. When two years old, transplant into permanent beds, which should be well and deeply manured. Make the beds four feet wide. Set out the plants twelve inches apart each way, and four inches deep. On the approach of winter clear off the bed, and cover with a dressing of manure, or compost; fork up the bed early in the spring, and apply a dressing of salt annually to the bed, after the season of cutting-which is not only beneficial to the plants, but will keep the bed clear of weeds.

\section{BEANS.}

30 cts. per quart.

(English Dwarfs.)

Feve de Marais, Fr. Haba, Span. Puffbohnen, Ger.

Early Mazagan.

BROAD WINDSOR.
Green Long Pod.

Horse.

To succeed well, these must be planted early, as the summer heat causes the blossoms to drop off prematurely. Plant early in March, in strong loamy soil, in drills two feet apart.

\section{BEANS}

25 cts. per quart.

(Dwarf, or Snap Shorts.)

Haricot, Fr. Frijoles, Span. Buschbohnen, Ger.

Early Six Weeks, or Mohawk. Cranberry Bush.

Early China Red Eye.

Refugee.

Early Yellow Six Weeks.

NeWINGTON WONDER.

Red Specisled Valentine. Turtle Soup, or Black Kidney.

Red French, or Marrow.

Dwarf Horticultural.

White Kidney or Royal DWarf.

The above list contains all that are really desirable. 
All the varieties of this class aretender and will not endure the cold. The Mohawk is considered the hardiest, and is generally the first planted. The Valentine is however, the favorite in the Philadelphia market, the pods being round and stringless. Plant about the middle of April, and at intervals throughout the season, for a succession, finishing about the end of July. The best mode of culture is in rows two feet apart, and the beans two or three inches apart. Keep well hoed, and draw the earth up to their stems.

BEATS.

40 cts. per quart.

(Pole or Running.)

Haricot a rames, Fr. Stangen bohnen, GER.

Large Ltma, $50 \mathrm{cts}$.

Carolina lima.

Scarlet Ronner.

White Dutch Runner.
Cranberry.

Horticulturat.

German Wax, 50 ets.

Dutch Case Knife.

Plant about the middle of May. The Lima Beans are very susceptible of cold and wet, and apt to rot in the ground, and should not be planted until the season is favorable and the ground warm. Fix poles in the ground four feet apart each way, and plant four to six beans about an inch deep around each pole. A shovel-full of rich, light and well-rotted compost to each hill would be beneficial. They may bo forwarded much earlier by sprouting them in a frame, under glass, and planting them out when the weather becomes mild, as they bear transplanting without any dificulty. The Horticultural and German "Wax Bean are superior varieties, either as snap shorts or shelled.

BEET,

$\$ 1.00$ per lb. 10 cts. per oz.

Betterave, Fr. Remolachas, Span. Rothe, oder Runkel rueben, Ger.

Extra-Early Turnip-rooted.

EARLy Red TURNIP-ROoted,

LoNa BLOOd RED.

Long Smooth Blood, (Radish- Yellow Globe Mangel Wurtzel. SHAPED.

The first four named are esteemed the best for table use. Sow in drills from April to June; thin out the plants to stand six or eight inches apart in the drills. The leaves of the Swiss chard are used as Spinach and the mib-rib of leaf dressed as Asparagus. The last three named varieties are used principally for feeding stock, and where extensively grown, the rows should be wide enough apart to cultivate with a horse hoe. 


\section{BORECOLE.}

20 cts. per oz.

C'hou vert, Fr. Berza, Span. Kohl, Ger.

Dwarf German Kale, $10 \mathrm{cts}$. per oz. Scotch Kale.

Tall German Kale.

Red, or Purple Kale.

An excellent green for Winter and Spring use. Sow from May to June. Set out the plants in July, in good rich ground. For early Spring use, sow the Dwarf German, in September, and protect over Winter, with a covering of straw or litter.

\section{BROCCOLI.}

50 cts. per cz.

Brocoli, Fr. Broculi, Span. Spargel kohl, Ger.

Purple Cape. Large Early White.

Produces heads in autumn like Cauliflower. The purple Cape is best adapted to our climate. Sow about the middle of May, transplant, and manage as winter cabbage.

\section{BRUSSELS SPROUTS.}

25 cts. per oz.

Chou de Bruxelles, Fr. Rosenkohl, Ger.

Produces from the stem small heads, resembling cabbages in miniature. The sprouts are used as winter greens, and become very tender when touched by the frost. Sow in May, transplant, and manage as winter cabbage.

\section{CABBAGE.}

25 cts. per oz.

Chou Pomme, Fr. Berza, Span. Kopf kohl, Ger.

EARLY York.

EARLy Oxheart.

Early Segar Loay.

WHEELER'S IMPERIAL.

LARGE EARLY York.

Earit Winnigstadt, $30 \mathrm{cts}$.

Earli Battersea.
Green Clurled Satoy.

Large Drumhead Savor.

Red Detch, for Pickling.

Red Drumhead, 30 ets.

Large Late Drumhead.

Flat Dutch.

LARge Bergen.

The first column contains the early sorts, which may be raised as follows: Sow the seed in well prepared ground, about the 15th of September. When the plants are large enough to transplant, pick them out of the seed bed, into frames. Protect the plants during severe. weather, with a covering of boards, observing to give them plenty of air and light during mild weather; they may also be raised 
by sowing the seed very early in hot-beds-afterwards plant out in deep and well-manured ground, in rows eighteen inches apart, and twelve inches distant in the rows.

The autumn and winter sorts, sow early in May, in a moderately shaded border, in shallow drills, three or four inches apart. Transplant early in July, in rows thirty inches apart, and about two feet apart in the rows. Cabbage succeeds best in a fresh rich soil, wellmanured and deeply dug or ploughed. The late plants are subject to attacks of the cabbage-fly, destroying them as fast as they appear above ground. Various remedies are recommended for the preservation of the plants, such as sprinkling them with ashes, air-slacked lime, plaster, or tobacco, which should be performed early in the morning. A solution of whale-oil soap is also recommended. [See subsequent page of this Calendar.]

\section{CARDOON.}

50 cts. per oz.

Cardoon, Fr. Cardo, Span. Kardonen, Ger.

Large Solid Stalked.

Is much cultivated in Europe for culinary purposes. The stems of the leaves, which are thick and crisp, after being blanched, are the eatable parts, and are generally used in soups or stews. They are in perfection during the autumn and winter. Sow in April, and transplant in trenches of well-manured ground; blanch by earthing up in the fall.

\section{CARROT.}

$\$ 1.25$ per 1b. $10 \mathrm{cts}$ per oz.

Carrotte, Fr. Zanahorias, Span. Moehren, Ger.
Earty Scariete Srort-Horn.
Early Horn.
Long Orange.
Half-Long Orange.
Altringham, or Field.
Large White Field.

The first three are the best kinds for table use. The Early Horn should be cultivated for spring and summer use; but the Long Orange is more suitable for main crops. For an early crop sow the seed, latter end of March, in well-dug, rich loamy soil, in drills about an inch deep and twelve inches apart.

The most suitable ground for late Carrots, is that which has been well-manured for previous crops, and requires no fresh manure. If the seed be sown in June, and the plants thinned out to the distance of five or six inches from each other when young, and kept hoed, they will yield an abundance of fine roots for winter and spring use. 


\section{CAULIFLOWER.}

$\$ 1.00$ per oz.

Chou Fleur, Fr. Coliflor, Span. Blumen Kohl, Ger.

EARLY LONDON:

EARLy Paris, $\$ 2.00$ per oz.

Asiatic.
LARge WALCHEREN.

LATE London.

Late Stadtholder, $\$ 2.00$ per oz.

The Early London and Large Walcheren, can be recommended as superior varieties.

Sow for early about the middle of September, in a bed of clean rich earth. In about four or five weeks afterward, the plants should be pricked out into another bed, at the distance of four inches from each other every way; these should be encompassed with garden frames; covered with glass sashes, and boards or shutters. The beds must be so secured, and the tops of the beds so covered as to keep out all frost, giving them light and air every mild day throughout the winter. Transplant in April into a bed of the richest earth, in the garden, at a distance of two feet and a half each way. Keep them well hoed, and bring the earth gradually up to their stems. The late variety matures in the autumn, and is sown and managed similarly to Cape Broccoli, but not so certain to succeed in this climate.

\section{CELERY.}

$25 \mathrm{cts}$. per oz.

Celeri, Fr. Appio Hortense, Span. Sellerie, Ger.

Dreer's White Solid.

Rose Colored Solid.

Sexmodr's White Solid.
Cole's Crystal White.

Ivery's Nonsuch, Red.

Celeriac, or Turnip-rooted.

Sow the last of March or early in April, in rich mellow ground, and in a situation where the plants can be protected from the parching heat of a summer sun; in dry weather water freely. When the plants are five or six inches high, transplant a portion in trenches well-manured, and repeat at intervals of two or three weeks for a succession. As they advance in growth, blanch by earthing up, which should be performed gradually in fine weather, taking care not to bury the hearts of the plants. The Celeriac, or Turnip-rooted, may be planted either on level ground or in shallow drills. The root of it swells like a turnip, and may be preserved in sand through the winter.

\section{CHERVIL.}

20 cts. per oz.

Cerfuil, Fr. Perifollo, Span. Garten Kerbel, Ger.

Used as a small salad, and for seasoning like parsiley. Sow in drills, in spring and at intervals. 


\section{CHICORY. (Large-rooted.)}

10 cts. per oz. 75 cts. per $1 b$.

The roots of this variety are dried and used as a substitute for Coffee. Sow in April. Cultivate like Carrots.

\section{CORN SALAD.}

$\$ 1.00$ per lb. 10 cts. per oz.

Mache, Fr. Ackersalat, GER.

Used as a small salad throughout the winter and spring. Sow in drills in August and September. Cover with straw on the approach of winter.

\section{CORN. (INDIAN.)}

5 cts. per ear. 25 cts. per qt.

Mais, Fr. Muiz, Spar. Welschkorn, Ger.

Adan's Early Market.

DarLing's EARLY SUgar.

Large SWeet, or Sugar.

Tuscarora.

Stowell's Evergrent.
Early Ganada.

White Flint, or Honiny.

Pearl, or Pop.

LoNG YELLOW.

Penna. Yellow.

Plant about first week in May and at intervals. The varieties in the first column are the best for table use. Adams's Early is the hardiest, and can be planted about the middle of April, and is the first corn that appears in the market, but cannot compare with the Sugar, or the Evergreen, which are, without question, the best for culinary purposes. The Sugar Corn bēing liable to rot in cold or wet ground, should not be planted until May; and for a succession, continue planting every two weeks, until the middle of July, in well-manured ground, in hills three feet apart.

\section{CRESS.}

10 cts. per oz.

Cresson, Fr. Alenois Mastuerzo, Span. Garten Kresse, Ger. Curled, or Pepper Grass. Broad leaved Garden. d as a small salad. Sow at intervals throughout the season.

\section{CUCUMBER.}

25 cts. per oz.

Concombre, Fr. Pepinos, Span. Gurken, Ger.

Early Russian.

Earlit Frame.

Early White-spined.
Long Green Turkey.

Simali Gherkin, or Burr (for PICKLING.) $40 \mathrm{cts}$. per oz.

The first three are the earliest and most esteemed table varieties. 
The White-spined retains its green color much longer than any other variety, and is principally grown for our markets. The Long Green and Gherkin are mostly used for pickles. For early use, plant about first week in May, on a warm and sheltered border. For pickles plant in the middle of July.

\section{ENGLISH PRIZE CUCUIBERS.}

In Packages; 25 cts. each.

Champion of England.

Sir Colin Campbelit.

General Canrobert.

Sion House, Improted.

RoMan Emperor.

Victory of Bath.

Conquerer of the West.

Kirkley Hall Defiance.
Millis' Jewess.

Snow's Horticultural Prizk

Kellway's Perfection.

Glory of Arnstadt.

Himalaya.

GLADiator.

LYNCH'S STAR OF THE WEST.

Godfrex's White Spint.

\section{Constantine Incomparable.}

These are the favorite varieties for forcing, frequently attaining a length of thirty inches. To grow them properly requires a skilful gardener, or much fuller directions than can be imparted in these brief remarks.

\section{EGG-PLANT,}

50 cts. per oz.

Melongene, Fr. Berengena, Span. Eierpflanze, Ger.

Earty Purple.

Large Purple.
Scarlet, 10 ets. per paper.

Long White, 10 sts per paper.

The first two are the kinds usually cultivated for table use-the others are fancy varieties.

Sow in hot beds early in march; transplant middle of May to first of June, in a rich warm piece of ground-about thirty inches apart. Draw the earth up to their stems when about a foot high. Egg-plant seed will not vegetate freely without substantial heat, and if the plants get the least chilled, in the earlier stages of growth, they seldom recover. Repeated sowings are sometimes necessary.

\section{ENDIVE.}

25 cts. per oz.

Chicoree, Fr. Chicoria, Spas. Endivian, Ger.

Green Curled.

White Curled.
Green Curled Moss. Broad-Leaved Batavian.

The Green Curled is considered the hardiest and best for salad. Sow in July, in shallow drills. When three or four inches high, transplant 
into good ground, at the distance of a foot apart. Blanch by tying up, which must be done when quite dry, or they will rot. At the approach of winter, the growing crops may be taken up carefully, with a ball of earth to each plant, and plant close together in a frame or dry cellar.

\section{KOHL-RABI, or Turnip-rooted Cabbage.}

20 cts. per oz.

Early White Vienna, 25 cts. Early Blue English.
“ Bute
“ 25 cts.
Large Late Biue.
“. White EngLish.
4. "W White.

This is a favorite regetable in Europe, especially on the continent, and should be grown in every garden. Sow in April, and transplant, in rows, twelve to eighteen inches apart. For late use, sow in June.

\section{KALE. [SEE BORECOLE.]}

25 cts per oz.

SEA KaLe.

Chou Marin, Fr. C l Marina, Span. See Kohl, Ger,

Is much esteemed in England, in some parts of which it grows spontaneously. The seed may be sown in October, or as early in the spring as the ground can be worked. For further directions, see Bridgman's Kitchen Gardener's Instructor.

\section{IEEK.}

20 cts. per oz.

Poireau, Fr. Puerro, Sran. Lauch, Ger.

Large Scotch Flag.

LARGE LONDON.

Large Musselburg, very fine, 30 cts. per oz.

Sow early in April. When the plants are four or five inches high, transplant in rows.

\section{IETTUCE.}

25 cts. per oz.

Laitue, Fr. Lechuga, Span. Garten Salat, Ger.

Earty Curled, or Cut Salad, Brown Deteh.

Eariy Yellow Steinkopf, one Curled India Head.

of the best for forcing. New Perpignaner, very solid

White Cabbage, or Butter. heads, stands heat, 50 cts. per oz.

Royal Cabbage, or Drumhead. Paris Green Coss.

Paris White, or Ice Coss. White Hammersmith.

The Early Curled is used as a cut salad, for which purpose it is sown thickly in frames, early in the spring, and somewhat later in the open borders; the Early Cabbage is a fine early "Head Salad;" the Royal 
Cabbage is a little later, and produces fine solid heads, and is much esteemed. To grow Head Lettuce fine, sow the seed in September; protect the plants during the winter, in frames, and plant out early in April, in rich moist ground, or sow in hot beds in February or March, and afterwards transplant.

\section{MUSHROOM SPAWW.}

Sold in the form of Bricks, 25 cts, each.

Champignon, Fr. Seta, Span. Champignon brut, Ger.

Culture.-Mushroom beds are best made under cover. A dry cellar or shed will do. Collect fresh horse-droppings without straw, turn them over three or four times, to get rid of the rank heat, dig out a foot deep of the space to contain the bed, lay some long manure at the bottom, and then the prepared dung, a little at a time, evenly and well beaten down until it is a foot above the ground, put a layer of light earth on this, two inches thick; after a few days when the rank heat has passed off, place the spawn in the bed in lumps about two inches square and six inches apart, then cover with light earth an inch thick; beat it gently down all over. Cover the bed thickly with straw, and if out of doors, keep off rain and protect from the cold with mats or boards. In about five weeks the mushrooms should make their appearance.

\section{MOSK-MELON.}

Melon Muscade, Fr. Melon Muscatel, Spav. Kantalupen, Ger.

JENNY Lind, 10 ets per oz.

Netted Citron, 10 ets. per oz.
Large Nutmeg, 20 cts per oz.

Persian, (very flne,) 25 cts. oz.

All the above varieties can be recommended. The Jenny Lind is a small early variety, the Citron and Nutmeg have long been the leading varieties in our market, and are of exquisite flavor; the Persian is a late variety of large size and superior quality. Plant early in May, in hills of rich light soil, six feet apart each way; allow three plants to each hill. When about a foot long, pinch off the tips, to make them branch. Observe not to plant pumpkins or squash near them.

\section{WATER-MELON.}

10 cts. per oz.

elon d'Eau, Fr. Zandia, Span. Wasser Melonen, Ger.

Motntain Sweet.

Early Mountain Sprout,

Black Spanish.

Citron, (for preserving,)
BRADFORD, 20 cts, per oz,

Pomaria, " " "

ORANGe, " " "

Apple Pie,

The Mountain Sweet is cultivated extensively for the Philadelphia Market, and stands deservedly the first on our list; when well-grown 
from pure seed, it eannot be surpassed for size and quality. The Bradford and Pomaria are varieties received from South Carolina, and highly recommended; the Apple Pie is also of recent introduction, and is prepared like apples for pies and sauces; the Orange is of small size, the flesh separates from the rind like an.orange. The Watermelon thrives best in a sandy soil, and should be planted in hills eight $f e$ t apart each way.

\section{MUSTARD.}

5 cts. per oz. 25 cts. per $1 \mathrm{~b}$.

Moutard, Fr. Mostazo, Span. Senf, Ger.

\section{White, (English.) : Brown.}

Sown like cress, and used as a small salad. The White Mustard seed is also used for medicinal purposes.

\section{NASTURTIUM.}

$20 \mathrm{cts}$. per oz.

Capucine, Fr. Capucina, Span. Kapuziner blume, Ger.

The seed-pods and foot-stalks are gathered green, and pickled in vinegar; resembling capers. Sow in April or early in May.

\section{OKRA, OR GOMBO.}

10 cts. per oz. $\$ 1.00$ per lb.

The green capsules of this plant are used in soups, stews, \&c., to which they impart a rich flavor, and are considered nutritious. Plant the seeds about the middle of May, in hills or drills. Plant the seed thickly, as it is liable to rot in the ground; rich ground is necessary.

\section{ONION.}

25 cts. per oz.

Oignon, Fr. Cebolla, Span: Zwiebel, Ger.

White or Silver Skinned. Large Yellow Strasburg.

\section{LARGe Red Wethersfield.}

The Silver Skin and Yellow Strasburg are principally grown in this vicinity. Sow the seed early in the Spring, very thickly, in beds or drills. As soon as the tops die off in the Summer, remove them to a dry airy place; and early the following Spring re-plant in rows about two inches apart, the rows wide enough apart to admit of hoeing. The Onions, by this process, are obtained of a large size early in the season. The Large Red Wethersfield may be reared to full size during the first season, by sowing in drills early in March, in strong land, and thinning them out to stand two or three inches apart, keeping them well hoed. 
Wнгте.

ONION SETS.

YELLOW.

Plant early in the Spring in rich ground, in drills six inches apart.

\section{PARSIEY.}

$10 \mathrm{cts}$. per oz.

\section{Curled, or Double. Extra Curled, 20 cts. per oz.}

\section{HAMBURG ROOTED.}

Sow early in April, in rows. Soak the seed first in warm water.

\section{PARSNIP.}

10 cts. per oz.

Panais, Fr. Chariberia, Span. Pastinake, Ger.

Large Stgar, or Hollow-Crowned.

This is decidedly the best Fariety. Sow early in April, in rich ground, well dug. Cultivate similar to carrots. The roots can remain in the ground for spring use.

\section{PEAS.}

Pois, Fr, Chicatos, Spax. Erbsen, Ger.

\section{Earliest.}

Dreer's Extra Early, very early and prolific, Height. Price Extra Early, (Northern growth) - * . $2 \frac{1}{2}$ " 30 Daniel O'Rourke, an early English variety, . . $2 \frac{1}{2}$ “ 25 Prince Albert, " " " . . . . . 2 $2 \frac{1}{2}$ " . 25 Tom Thumb, or Allen's Dwarf, . . . . 10 inches, .50

This is the best Early Dwarf Pea; requires a rich soil, and is well suited from its dwarf habit for small gardens; a good bearer.

\section{second Early.}

Early Frame, or Washington, . . . . 3 feei, $\$ .25$

Bishop's Dwarf, prolific, . . . . . . $1 \frac{1}{2}$ " $\quad .40$

Prize-taker, new. $\quad$. . . . . . . 4 6 40

\section{For General and Late Crop.}

*Champion of England. (one of the best,) • - 8 " 50

Dwarf Blue Imperial, a favorite variety, - . $2 \frac{1}{2}$ " 25

*Hair's Dwarf-Green Marrow, fine, . . $2 \frac{1}{2}$ " .50

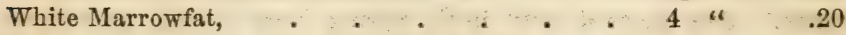

Black-eye Marrowfat, . _ . . . . . . 3 is 20

*Napoleon, or new Dwarf Climax, . . . . $2 \frac{1}{2}$ " 50

*Eugenie, or Alliance, . . . . . . . . . $2 \frac{2}{2} 66 \quad .50$

Victoria, or Waterloo Marrow, . . . . . . . 5 to 6 4 .30

Those marked thus * are wrinkled marrows, the finest flavored of peas.

The above list contains all the leading varieties-and quite sufficient to suit all purposes. 
Commence planting the early kinds as early in the Spring as the ground can be brought into good condition. All the other sorts will answer for succsssive crops. To have Peas during the Summer and Autumn, plant in June, July and August, in single or double rows, from two to four feet apart, according to heighth. Dreer's Extra Early is the best for late planting. In hoeing draw the earth up to their stems.

\section{PEPPER.}

50 cts; per oz.

Piment, Fr. Pimiento, Span. Pfeffer, Ger.

Large Sweet Bell Shaped. Cayenne, or long. Tomato Shaped.

Cherry.

The Bell Shaped and Tomato are used, when green, for pickling The Bell Shaped is quite mild, and attains a large size. Sow in hot beds in March, or on a warm border early in May. Transplant in good rich ground, from 18 to 24 inches apart.

\section{PUMPRIN.}

Courge, Fr. Calabaza, Span. Kuerbis, Ger.

Cashaw, (Crooked-necked.) $10 \mathrm{cts}$. oz. Field, $25 \mathrm{cts}$. per qt. Маммотн, 25 ets. per oz.

Large Cheese, 50 cts. per qt.

Plant in May, in hills, eight or ten feet apart each way. The Cashaw is generally preferred for cooking.

\section{RADISF.}

$\$ 1.25$ per $1 \mathrm{~b} .10 \mathrm{cts}$ per oz.

Radis et Rave, Fr. Rabano, Span. Rettig, Ger.

Earix Soarlet Olive Shaped. Yellow Turnip, or Summer.

Long Scarlet Short Top.

White Naples, or Summer.

LONG SALMON.

White Turnip-rooted.

White Spanish, or Winter.

BLACK SPANish, OR Winter.

Red Turnip-rooted, or Ceerry. Scarlet China Winter.

The first column contains the varieties used for early sowings, which should be made as early in the Spring as the ground can be worked, on a sheltered border. The ground should be well-manured, dug, and raked. The Yellow Turnip, and White Naples are exclellent varieties for Summer use.

\section{RHUBARB.}

25 cts. per oz.

Rhubarbe, Fr. Ruibanbo, Span. Rabarber, Ger.

Victoria.
Linnaus,
Magince Albert.

The stalks of this plant are used for pies and tarts. It is fit for use before green fruit appears, and is an excellent substitute. Sow in 
April ; transplant the ensuing Autumn or Spring to any desired situaton, in deep and heavily manured ground. As no dependence can be placed upon growing the varieties true from seed, it is recommended to those who desire a choice article, to procure the roots. We offer the following choice varieties of

\section{RHUBARB ROOTS.}

20 to 25 cents each; $\$ 2$ to $\$ 1$ per dozen, according to size. These are not Seedlings, but propagated from the true varieties.

Myatt's Linxeeds.

Mitatt's Victoria.

Magnum Bonum.
Prince Albert.

Mitchell's Royal Leakington, blood red.

To grow the stalks in perfection, the ground must be dug and heavily manured, at least two feet deep, Set out the roots three feet apart each way.

\section{SALSIFY, OR OYSTER PLANT.}

25 cts. per oz.

Salsifis, Fr. Barba Carbuna, Span. Bocksbart, Ger.

A fine vegetable used as carrots; or, after being boiled, made into cakes with paste, and fried Jike oysters, which they resemble in flaror. Cultivate same as Parsnips; it is also hardy and can remain in the ground.

\section{SCORZONERA.}

25 cts. per oz.

Scorzonere, Fr. Eescorconera, Spax. Schwartzurzel, Ger.

Known also as Black Salsify. It is cultivated and used in the same manner as the Salsify.

\section{SORREL. (GARDEN.)}

10 cts. per oz.

Oseille, Fr. Acedera, Span, Sauerampfer, Ger.

Used as a salad. Sow in April, in shallow drills; thin out the plants to twelve inches apart.

\section{SPINACE.}

50 cts. per 1b. 10 cts. per oz.

\section{Epinard, Fr. Espinaca, Span. Spinat, Ger.}

Round Leaved Savor.

Prickly Seed.

For Spring and Summer use, sow as early as the ground can be worked. For Winter and early Spring use, sow in September, in well manured ground; cover with straw on the approach of cold weather.

\section{SQUASH.}

10 cts. per oz.

Giraumon, Fr. Calabaza, Span. Kurbis, Ger.

Early Bush, or Pattr Pan. Cocoa Nut or Valparaiso.

Early EgG, or Appie, bush. Boston Marrow.

Long Green Crook-neck. New Hubbard, $20 \mathrm{cts}$. per oz. 
The varieties in the first column, are the best for summer use, and the Boston Marrow and Hubbard, are superior winter varieties. The Early Bush appears to be the favorite variety for summer use, as it is more extensively grown than any other, and being of a bushy habit, is more suitable for small gardens than the running kinds. Plant in hills in the same manner, and at the same time, as Cucumbers and Melons. The bushes three or four feet apart, and the running kinds from six to nine.

TOMATO.

Tomate, Fr. Tomates, Span. Liebes Apfel, Ger.

Extra Early Red, per oz. 50 cts. Mammoth, per oz. 50 cis. Large Smooth Red, “ 25 " Large Yellow, “ 25 “ DWARF RED, " " 50 “ ReD \& Yellow Cherry “ 50 “ Fejee Island, " 50 " Yeliow Plum, " 50 “ The Cook's Favorite, new, the best red smooth, solid variety, -25 ets. per paper?

The varieties in the first column are the most desirable for culinary purposes, and ripen in the order in which they are arranged on the list. The Fejee Island is decidedly the best for family use, being of good size, solid, and well flavored, and an abundant bearer, but somewhat late in ripening. For putting up in cans for winter use, it has no superior, containing less water and seeds than any other variety. The Dwarf Red is a fine variety, valuable on account of its dwarf-bushy growth. For early use, sow in hot-beds, early in March, and plant out in May, from three to four feet apart.

\section{TURNIP.}

75 cts. per Ib. 10 cts. per oz.

\section{Navet, Fr. Nabo, Span. Steck-reuben, Ger.}

White Fiat Dutch, strap-leaved.

Purple or Red Top, Robirtson's Golden Ball.

EArLy Yellow Stone.

White Norfolk.

Long White French.
White GLobe.

Yellow Aberdeen, a Scotch. Waite's ECLIPSE.

Purple top Ruta Baga. Golden Globe Ruta Baga. White Ruta Baga, or Swedish.

The first three on the list are the best for table use; the Flat Dutch, is usually sown for early summer use, quite early in the Spring, and also with the Purple Top in July and August, for a main crop.Robertson's Golden Ball is of recent introduction, and is highly recommended for culinary purposes. The Glcbe, Norfolk and Ruta Baga are principally used for feeding stock. Sow in July, in drills two feet apart, and thin out to stand six inches apart. Keep the ground well stirred and clear of weeds. As Turnips are grown principally for 
BIRD SEEDS, \&C.

Selected of the best quality, free from mustiness and other impurities, so destructive to birds.

$\begin{array}{ll}\text { Canary. } & \text { Maw. } \\ \text { Hemp. } & \text { Rough Rioe. } \\ \text { Millet. } & \text { Yeliow. } \\ \text { Rape, or Colf. } & \text { Lettuce. } \\ \text { Bird Baskets. } & \text { Hair for Nests. } \\ \text { Bath Cups. } & \text { Cetthe Fish Bone. }\end{array}$

\section{TOBACCO SEED.}

Havana, $\$ 1.00$ per oz. Virginia, 50 ets. per oz. Connecticut Seed-Leaf, 50 cts. per oz.

The above are the best varieties. The culture of Tobacco is one of the most profitable. It will grow on any soil; but a deep mellow loam, plowed in the fall, and cross-plowed in the spring, and well-manured, is best adapted to it. The seed should be sown in the spring as soon as the frost is out of the ground, on a clean well-prepared piece of ground, in a warm, sheltered situation. Care should be taken to protect the plants from frost. Transplant about the 1st of June, in rows about three and a half feet apart. The culture of this plant is very much the same as that usually adopted for Indian Corn, in stirring the ground and keeping down the weeds.

\section{ESCULENT ROOTS, PLANTS, \&C.}

Early Potatoms.

Chives.

Garlic.

White Onion Sets.

Yellow Onion Sets.

Potatoe Onion.

Cabbage Plants.

Celert "

EGG
Tree, or TOP ONion.

Mushroom Spawn.

Asparagus Roots.

Sweet Potato Suips.

Sea Kale.

RHUbaRb Roots.

Lettuce Plants.

Tomato Plants.

Pepper Plants.

Dealers supplied with seeds in bulk, or neatly put up in packets, distinctly labelled, ready for retailing, on the lowest terms. 


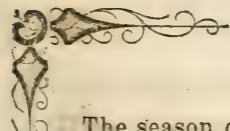

\section{NEW VEGETABLES.}

The season of 1863 having been an unfarorable one for the trial of (1) new regetables, many crops haring failed in the ricinity, we have but 6 few to offer. After several years trial, we can recommend to our customers, a new Tomato; called for its excellent qualities,

\section{"THE COOR'S FAVORITE."}

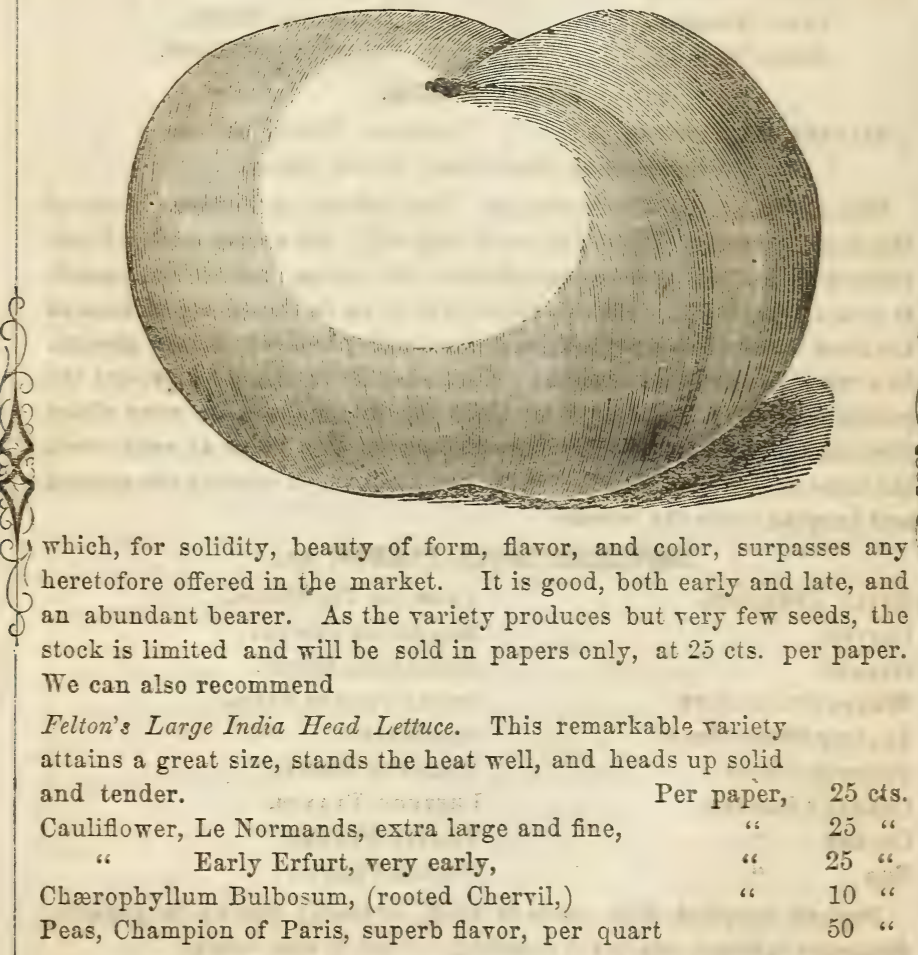

Among old and well-tried rarieties, Dreer's Extra Early Peas still take the lead among our gárdeners as the most early, productire and $\$$ even cropper. We also supply largely to all the market gardeners in (1) this vicinity, our Large Early York Cabbage, which is sown by them in September, and treated as directed under head of Cabbages, for early use. Te have many new rarieties under trial, of which we hope to make a favorable report another season, 


\section{FLOWER GARDEN.}

Although to the mere economist, flowers are not indispensable or directly remunerative, yet they have become so to the civilized, intelligent, and intellectual community in which we live. The most humble cottager, unless deficient in the most simple conceptions of beauty, must have his flower-plot, and one or more varieties of flowers. The enthusiastic amateur is no longer content to receive his floricultural novelties at second-hand, but must have them direct from the great European centres of Horticulture. We have latterly endeavored to render this necessity of the amateur importing a few seeds or plants, unnecessary, by constant attention to obtain every highly recommended novelty, and after testing it, to offer it with our opinion of its merits. We shall continue to do this, and shall endeavor to have, at the earliest day, every valuble acquisition in seeds, bulbs or plants.

Little pains are taken to have the soil of the flower-beds and borders, in a friable, active state, not subject to bake. This is what renders it so difficult for small flower-seeds to survive germination, and for the delicate transplanted annuals to make a start. All that the flower-border or beds require, is a dry bottom, with an annual supply of prepared compost, made up of barn-yard manure, leaf-mould, or decayed leaves from the woods, and such other refuse as may appear suitable to enrich the heap. With different soils, special applications will be necessary, as stated under the head of Esculent garden. The Hot-bed frame as there described, will serve for the purpose of the Flower garden. The only alditional requisites are flower-pruning scissors, stakes for tying up plants, labels and flower-pots.

Thz LAws, which adds so much to the neatness of the Garden, may be extensive or limited in size, but should always be well prepared and neatly kept. Much of the beauty of the lawn is also due to the variety of grass seed sown. The usual practice has been to employ a mixture of several species, which is prepared for sale. Our Lawn grass mixture consists of five varieties, viz: Sweet Vernal, Green Grass, Blue Grass, Herd Grass, and White Clover. From one and a half to two bushels is the quantity generally sown to the acre. Persons who prefer a different mixture, can have it made up to order.

The Flower-beds may be cut out in the lawn, and in these, bedding 
plants from the green-housc planted, as soon as the weather becomes suitable; also, choice annuals somm. The folloming brief directions will be found reliable.

\section{Directions for the Sowing and Hanagement of Flower Seeds}

Provided the soil is in a proper state, fiower-seeds may be sown in the open border, in the months of April and Mar; the best criterion is the state of the soil. The seeds should be sown as soon as the soil becomes dry and friable, after the spring frosts hare disappeared. Care should be taken not to sow in a crowded border, as light and air are indispensable. They may also be sown in prepared beds, to be transplanted to the garden. The former is the more simple method, but not always satisfactory, as during the interral between the sowing of the seed and the period of blooming, the ground occupied is not attractire. The changes of climate, heary rains and drying winds, with hot sun, renders the surface of the soil unfit for the germination of small seeds.-As to the depth to which seeds should be corered, the best general rule is, to cover fine and light seeds rery lightly, just enough to protect them from the sun; and in extremely dry weather, a sprinkling of damp moss is rery useful. Sereral rarieties are so tender as to require special attention, such as the Calceolaria.

Many annuals are rery desirable for the Green House, when sown in early fall. Of these the most important are Sreet Alyssum, Candytuft, Mignonette, Lobelia, Schizanthus, German Siocks, Browallia and sereral others; these are for winter blooming. Many rarieties, as well as the abore, mas be sown later, for blooming early in spring, such as Pansy, Ageratum, Antirrhinums, China Pink, Dianthus Heddewegii, Lacinatus and Sinensis, Acroclinum Roseum, Linum Grandifloruin, Mimulus, Myosotis, Petunias, Phlox Drummondii, Salpiglossis, Terbena, $\hat{c}$. For sowing in pots, or seed-pans, the following directions will be found suitable:

The best soil is a mixture of equal parts of sand, leaf-mould, and loam, which should be thoroughly mixed; then fill your pots or boses to within one-half inch of the rim; press the soil firmly and erenly in the pot, which can be done most conreniently with the bottom of an empty flower-pot; then sow your seed erenly orer the surface, and, with the addition of a little more sand in the same suil, corer the seeds according to their size, say from one-eighth to one-quarter of an inch, then press the soil as before, even and firm with the bottom of a flowerpot; water sparingly, enough to keep the soil moist, aroiding either extreme. As soon as the plants appear, they will require your careful attention, as the least orer-watering may cause them to "damp off," and suddenly destroy all your hopes. Ther should now hare as much sun 
possible, and when the weather is pleasant, some air may be admitted. As soon as the plants are large enough to handle, pick them out of the seed-pot; in other words, transplant them into another pot, placing them about one inch apart; they must be shaded for a few days from the sun, until they are established. When large enough, they can be planted separately into small pots, and kept thus until the proper season for planting out in the garden.

BIENNIALS.-These do not usually bloom until the second season after sowing. They may be sown out of doors, at least those that are hardy, while a few very desirable ones had better be sown in pots. The following are among the most desirable,-Wall-flower, Forglove, Pinks, Sweet William, Antirrhinum, Hollyhock, Larkspur, Canterbury Bell, and others.

CALCEOLARIA.-As this very desirable flower requires a little special care, the following method should be adopted. The seed should be sown in the latter part of August, or beginning of September, in pots prepared in the following manner: the pot to be half-filled with drainage, over that, the rough sifting of the mould, and the surface covered with soil as fine as possible, half of which should be composed of river sand. When prepared thus, it should be watered with a fine rose, immediately after which sow the seed carefully, without any covering of soil. The pots should then be placed under a close frame or hand-glass, in a shady part of the garden, no artificial heat being required. In large establishments, of course there are propagating or other houses that will do, where the same kind of moist temperature could be obtained, but any exposure to the sun must be carefully guarded against by mats or paper. If the situation is of the proper temperature, they will require watering but very seldom. Directly the seedlings are strong enough, they must be picked off in pots prepared as before, and placed in the same situation: from the store pots they will require to be potted off singly; after this the plants will grow very rapidly. Through the winter, the plants will thrive well on the shelves near the glass, in the green-houses; and, to obtain fine specimens, they must be shifted on freely till the flower-stalks have started, and should always be smoked with tobacco directly the green-fly appears, as no plants in cultivation so readily suffer from this insect as the Calceolaria.

It is necessary to remark, that one of the most frequent causes of the appearance of these injurious insects, is the plant becoming root-bound; to avoid which evil, it is important that it should frequently be re-potted during the growing season.

CINERARIA are more hardy in their growth, and require somewhat less care than the above, but for them the same treatment will suit in 
sowing of seed, \&c. If required to flower in the winter, seed should be sown in April and May, and in the following months for spring flowering.

CLIMBERS, for garden decoration, should be sown in January, February, and March, the earlier the better, as the display for the after season will be in proportion to their early vigor for planting out; such as Cobca, Thunbergia, Maurandia, Lophosphermum, Calampalis (Eccremocarpus) and Tropcoolum of sorts.

CLEMATIS species amongst hardy shrubs, and PENTSTEMON, amongst herbaceous plants, are prominent instances of seeds which remain long dormant, often a whole year, before they grow, hence the importance of sowing them as soon as ripe.

Another class often fail to germinate in consequence of the thickness, or hardness, of the outer skin or integument. We have had seeds of the Erythina and Canna for months in the ground perfectly dormant, which upon being soaked in hot water for one week have germinated finely.

It should be borne in mind, that much of the disappointment that occurs in the sowing of Flower seeds may be obviated by attention to the foregoing hints.

In the following list we have included all the really desirable novelties, as well as the standard varieties which have been fully tested in this vicinity.

\section{Flover Seeds by . Fail.}

Their portability renders them so easily and cheaply transported by mail, that no one with any pretensions to taste in Floriculture need be without a choice selection. For the accommodation of those who are unacquainted with the varieties, we have put up the following assortments of the most desirable free blooming and showy kinds, which will be promptly mailed (prepaid) upon the receipt of a remittance.

Correspondents will please write their names legibly, and in full, with post-office, county and state.

No. 1.-Twenty-five choice annuals, free bloomers, for $\quad$. $\$ 1.00$

No. 2.-Twenty choice annuals, biennial and perennial varieties, 1.00

No. 3.-Twelve new and rare varieties, . . . . . 1.00

No. 4.-Twenty varieties, for Green-house culture, . . . 3.00

No. 5.-One hundred varieties, including many new and rare sorts, 8.00

As an inducement to POSTMASTERS AND OTHERS, forming Clubs, we will forward, post-paid, six One Dollar packages for a remittance of Five Dollars.

At these prices, invariably our own selection. The latest novetites $a \cdot e$ not included in these collections; but a liberal discount will be made fiom catalogue price when ordering a quantity. 


\section{Novelties for 1864,}

Principally received from Europe. Descriptions as given by the growers :

ASTER, NEW VICTORIA...Carmine rose, flowers as large as the Emperor Aster, habit pyramidal, per paper.................. .25

"6 REID'S NEW...Taller than the quilled; Flowers, globe shaped, and beautifully quilled............................ .10

6s SPLENDENS...(Jones'), color cream white. Early..... .25

ANTIRRHINUM DELILA...Carmine, with white throat............. 10

BROWALLIA ABBREVIATA... Of dwarf compact growth, flowers deep rose, white eyed, flowering freely ...................... .25

BIDENS ATROSANGUINEA...New and beautiful.....................20

CALLIRHOE VERTICILLATA...An extremely floriferous creeper, flowers of the same color, but double the size of $C$. pedata... . 50

DATURA ATROVIOLACEA PLENISSIMA...Introduced by Dr. Weber from Cochin China, $4 \frac{1}{2}$ feet high; the outside of the flowers violet, nearly black; the inside somewhat lighter......

DATURA TEXANA...Flowers very large, measuring $8 \frac{1}{2}$ inches in diameter, sweet scented, color creamy white, a native of Texas, .25

DIANTHUS. BARBATUS FLO. PLEN...Double Sweet William...... .20

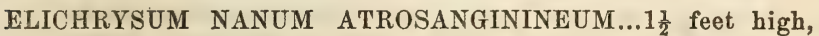
brilliant deep crimson flowers, a very beautiful variety of the Everlasting flower

EUTOCA ORTGIESIANA...A new species, nearly creeping in its habit, introduced from Mexico, flowers light and dark lilac... .25

GODETIA ROSEA-ALBA, TOM THUMB....Flower pure white, with a brilliant rose blotch at the base of each petal, blooms in profusion, height 1 foot.

HELIPTERUM SANFORDII...This very pretty and distinct annual Everlasting is of a dwarf tufted habit, growing on ordinary soil, about 9 inches high, with neat oblong lanceolate entire foliage, and large globular clusters of bright golden yellow flowers. It is not only a valuable addition to our summer flowers, but is also an excellent plant for winter bouquets; its flowers remaining long in perfection-per packet............. .50

HELIPTERUM ANTHEMOIDES-An older but very beautiful variety of the above.............................................. ,

IPOMOPSIS, ROSEA. CUPREATA.

“. JAUNE CANARIE, (canary yellow.)

Three new varieties of this favorite ornamental plant, each... .25 
IPOMEA QUAMOCLIT COCCINNE; STAR IPOMEA...This is believed to be a deception, being only the old Scarlet Morning Glory.

IPOMEA TRI-COLOR...A new and fine variety

LUPINUS VENUSTUS TRI-COLOR...A very pretty new Lupin, with handsome deep green foliage, flowers purple, white and blue, height 2 feet.................................................. .

LUPINUS DUNNETTI ATROVIOLACEUS...Flowers dark violet, .25

LINUM CANDIDISSIMUM...A perennial variety, large flowering, snow white .10 seeds, .25

MIMULUS HYBRIDUS TIGRINUS...A really charming and valuable acquisition. The magnificence, diversity, and great profusion of its flowers, as beautifully tigered or spotted as the Tigered Calceolarias, and Tydeas, as well as its dwarf compact growth, robust habit, (standing the sun much better than the other varieties), will soon make it a general favorite.

PHLOX DRUMMONDII, CHAMOIS ROSE...A quite new, exceedingly distinct and delicate color, constant........10 seeds,

RHODANTHE ATROSANGUINEA...This beautiful and very distinct species, differs from R. Maculata, in its dwarfer and more branching habit; longer and more pointed foliage, and especially by the color of its flowers, which have the entire disk of a dark violet or crimson brown shade. The ray scales are of a bright purple or Magenta color................ .50

RHODANTHE MACULATA ALBA.-This charming variety which proves to be a sport from the beautiful R. Masulata, introduced last season, and differs only in the color of the ray scales, which are of the purest and most silvery white, it is unquestionably the finest white Ererlasting in cultivation.......

SOLANUM CAPICA8TRUM...A dwari rariety, with red, cherrylike fruit, quite ornamental in pots, in the green-house during

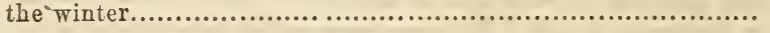

SOLANUM MARGINATUM...Beautiful............................... .25

SENICIO ELEGANS NANA...Dwarf, double white..................... .25

" " " " 6 A double dark rose.................. .25

" " " "

" " . . " Dwarf, double purple................ .25

The above are beautiful new varieties, of the Jacobea or Senicio, of dwarf habit, and great profusion of flowers.

VERBENA HYBRIDA, NEW ITALIAN STRIPED...In most brilliant colors, all carnation like striped, rose, lilac, violet, purple, crimson, \&c................................................. .50

ZINNIA ELEGANS COCCINNEA, FL. PL.... Double scarlet....... .25 


\section{Novelties and Select Flowers of former seasons, WORTHY OF SPECIAL ATTENTION.}

\section{Price, 10 cents per paper, except where noted.}

The letters preceding the varieties, denote:-b. biennial, or such as last two seasons; $p$. perennial, or such as exist from year to year; $t$. tender, which will not endure the frost; t. $p$. tender perennial, which require the protection of a green-house during the winter; $\bar{l} . h$. half hardy, requiring some protection; $c$. climbers; a * denotes that although the variety may be biennial or perennial, it will bloom the first year. if sown early; the remainder are annuals, which arrive at perfection and die off the first year.

ABRONIA UMBELATA, trailing, clusters of rosy lilac blossoms. ACROCLINIUM ROSEUM, rose color, everlasting flower. ACROCLINIUM ROSEUM ALBUM.-A pure white variety. AGERATUM CELESTINUM NANUM.-Dwarf, useful for bedding out. ALYSSUM BENTHAMII.-New white Sweet Alyssum.

AMARANTHUS MELANCHOLICUS (var. ruber.) Introduced by Mr.

Veitch, from Japan. Its habit is very compact, height 12 to 18 inches, with striking blood-red foliage. A very fine-foliaged bedding plant, valuable for flower-garden decoration, 20 cts.

h.b. ANTIRRHINNUM PAPILONACEUM. Deep blood-red, pure white throat, splendid.

ANAGALLIS.-Dwarf, compact, flowering plants; admirably adapted for ornamental baskets, rock work, etc. The choicest varieties are,-Grandiflora Rosea, rose colored, and Grandiflora

Carulea, large sky-blue. Phillipsi Grandiflora, sup. blue. h.b.*ANTIRRHINUM BRILLIANT, bright scarlet with white throat. h.b.* " " HENRY IV., dwarf, white, crimson and scarlet. $h . b . * \quad$ "FIRE FLY, orange scarlet, white throat. APHYLLANTHUS MONSPELLIENSIS.

p. AQUILEGIA.-Fine double Columbine; saved from named varieties. ASTERS, NEW EMPEROR.-Flowers of great size, very double, and fine form and colors, 20 cts.

ASTERS, NEW CHRYSANTHEMUM, FLOWERED.

ASTERS. (See "German Flower Seeds in assortments," page 18.) BALSAMS, CAMELLIA FLOWERED, very double and fine colors.

" "6 6 dwarf, superb colors.

"new, rose flowered.

CALFNDULA PONGEI, FL. PL., double white, hybrid marigold.

CALLIRHOE PEDATA, (Nuttalia.)-A very beautiful summer flowering plant, from one and a half to three feet in height, with rich violet or purple crimson close petaled flowers with white centre, each two inches or more in width, and partially cupped, yielding a succession of its numerous attractive blossoms throughout the summer. 
CALLIRHOE, PEDATA NANA, a superb dwarf variety, $20 \mathrm{cts}$.

CALLIOPSIS CARDAMINE FOLIA HYBRIDA, brilliant yellow flowers, $20 \mathrm{cts}$.

t.p. ${ }^{*}$ CANNA INDICA, or shot plant.

" GIGANTEA.

"WARSCEWICZII, dwarf, blood-colored.

The Cannas are a stately species of plants, highly ornamental, producing a very rich and Oriental effect, by their large, broad, massive foliage, terminated by racemes of crimson or scarlet variously lobed flowers.

CHAENOSTOMA FASTIGIATUM FL. ALBA. A new white variety of this charming annual:

CLARKIA PULCHERRIMA, pure brilliant crimson.

t.p. ${ }^{*} \mathrm{COB}$ 压A SCANDENS, large, blue bell-shaped flowers, climber.

COCKSCOMB, CELOSIA CRISTATA NANA.-The true dwarf variety,

producing immense heads of rich, velvet-like crimson combs.

CONVOLVULUS TRICOLOR SPLENDENS.-Dwarf Convolvulus.

CONVOLVULUS CANTABRICUS, Rosy-purple, beautiful trailer for hanging baskets, $25 \mathrm{cts}$.

$p$. DAISY, (Bellis perennis,) finest double imported, $20 \mathrm{cts}$.

t.p.*DAHLIA.-Saved from fine double varieties, 20 cts.

t.p.*DATURA HUMULIS, a rare and ornamental plant, with large conspicuous, double drooping flowers, trumpet-shaped, of a rich nankeen yellow, delightfully fragrant, 20 cts.

t.p.*DATURA WRIGHTII, (Meteloides,) white, bordered with lilac.

h.h.p. DIANTHUS CARYOPHYLLUS, FL. PL., fine imported, Double. GERMAN CARNATION, from named var., $50 \mathrm{cts}$. h.h.p. " " CARYPH. REMONTANT.-MONTHLY CARNATION, imported in packets, 50 ets.

b.* " " CHINENSIS HEDDEWIGI.-A superb variety of the China Pink.

b.* " HEDDEWIGI, HYBRIDUS IMPERIALIS, dwarf and compact growth ; fine for pot culture, $25 \mathrm{cts}$.

b.* " $\quad$ HEDDEWIGI, FL. PL.-A fine double variety of the original type, beautiful colors, $25 \mathrm{cts}$.

b.* “ HEDDEWIGI, FL. PL., ATRO-PURPUREA.-A very dark crimson double variety, $25 \mathrm{cts}$.

b.* " $\quad$ LACINIATUS.-Remarkably large blossoms of superb colors.

$h . b$ *DIANTHUS CHINENSIS NANUS, VAR. ATRO-SANGUINEUS PL.-A fine acquisition; the plant is five inches high, flowers globular and profuse; color, dark blood-red, $20 \mathrm{cts}$. 
h.b.*DIANTHUS Chinensis, FLORA PLENA ALBA.-A pure white variety of the China Pink.

h.b. DELPHINIUM TRI-COLOR, three-colored Larkspur.

h.p. " " FORMOSUM, splendid hardy perennial Larkspur, brilliant blue flowers; flowers the first year if planted early. h.p. DELPHINIUM, MONS. MEUNER. Fine large blue, per. Larkspur, 25 cts.

EGG PLANT, SCARLET CHINESE, very ornamental. EUCHARDIUM, GRANDIFLORUM ALBUM, blush-white. EUCHARDIUM GRAND : ROSEUM, a blush-colored variety. FENZLIA DIANTHIFLORA, a profusion of rosy-lilac blossoms; 20 cts. h.p.*GAURA LINDHEIMERA, spikes of white and red tinted blossoms.

GAILLARDIA PICTA, painted yellow, \& red ; fine bedding plant, 5 cts. t.p. GLADIOLUS, new French hybrid varieties, 20 cts. GODETIA THE BRIDE. Color white and crimson. GYPSOPHILLA MURALIS, pink, suitable for hanging-baskets.

h.p. " " PANICULATA, a hardy perennial; flowers are beautiful for bouquets, imparting a light airy appearance.

HEARTSEASE.-See Pansy.

HELICHRYSUM MACRANTHUM, the finest class of large, beautiful, everlasting flowers; a succession of bloom umtil frost.

h.b. HOLLYHOCKS, superb English varieties mixed.

"assortment of 20 beautiful colors, each separate- $\$ 1.00$

c. IPOMEA LIMBATA, violet margined with white.

c. " " STRIATA, NOVA., three-colored.

c. " RUBRA CFRULEA, RED AND BLUE. 20 cts

t.b. IPOMOPSIS ELEGANS SUPERBA, orange and scarlet.

b. LARKSPUR, NEW CHAMOIS, beautiful.

b. " white branching.

LINUM GRANDIFLORUM RUBRUM, superb scarlet flax.

LINARIA CYMBALLARIA, KENILWORTH IVY, suitable for hanging-baskets.

LOBELIA ERINUS SPECIOSA, compact growth, fine for vases. This variety blooms during the entire summer in the open borders; flowers of a superb ultra-marine blue.

“ ERINUS COMPACTA ALBA. Fine pure white, 25 cts.

“ TRIGONICAULIS, large sky-blue flowers, white eye.

LUPINUS HARTWEGII CELESTINUS, light-blue, shaded with rose.

LYCHNIS HYBRIDA HAAGEANA, very beautiful large brilliant orange-scarlet, and light and dark crimson, white-flaked flowers, dwarf and free-flowering, 20 cts. 
c. MAURANDIA, species. A beautiful tribe of slender-growing rapid climbers, blooming profusely until quite late in the autumn. The varieties are,-Albiflora, pure white; Barclayana, purple; Rosecm, dark rose.

MIMULUS, or MONKEY-FLOWER.-Showy flowers, suitable for the green-house or moist shady situations in the garden.

"MOSCHATUS, Musk Plant; fine in hanging-baskets.

“ QUINQUEVULNERUS, MAXIMUS, very large and finely spotted varieties, showy and effective:

" ROSEUS PALLIDUS, pale rose flowers.

“ ROSEUS PALLIDUS VAR. FL. ALBA, (Benary.) A new white variety, quite constant, of Mimul. roseus pallidus, introduced some years ago, 20 ets.

" VARIEGATUS, white ground.

" CUPREUS. Introduced by Mr. Veitch from the Andes of Chili. A beautiful plant producing a profusion of the richest orange crimson flowers. 4 to 6 inches high, $25 \mathrm{cts}$.

MYOSOTIS, or FORGET-ME-NOT.-Neat and beautiful little plants; succeed best in a shady situation. The varieties are,-Alpestris, Alpine; Azorica, Azorean; Azurea Grandiflora, large flowered; Palustris, true forget-me-not; Paltstris Alba, white.

NASTURTIUM, (Troprolum.) - The varieties are all desirable, either for the flower border, for pots, or green-house culture. The following are the most choice:-

" TOM THUMB, very dwarf, scarlet.

". " " " yellow.

" " BEAUTY, orange-spotted.

“ CARTER'S CRYSTAL PALACE GEM. Dwarf variety, : sulphur col. flowers, having a dark red spot near the base of each petal. It is densely corered without interruption from June until frost with its bright yellow flowers, $20 \mathrm{cts}$.

c. Schedermani, straw color; c. Lilli Schmidt, orange scarlet. CENOTHERA, ROSA, a new dwarf rose-flowering annual, 20 cts.

“ BISTORTA VEITCHIANA, neat dark yellow.

“ DRUMMONDII NANA, a golden yellow blossom.

OXALIS ROSEA, dwarf, with clusters of bright rose-colored blossoms. PANSY, (Viola tri-color maxima,) good imported.

“ DREER'S REMIUM VARIETIES, saved from first-class flowers, with special directions how to cultivate; 50 cts. Second quality, “ 25 cts.

“ best English Imported, 25 cts. 


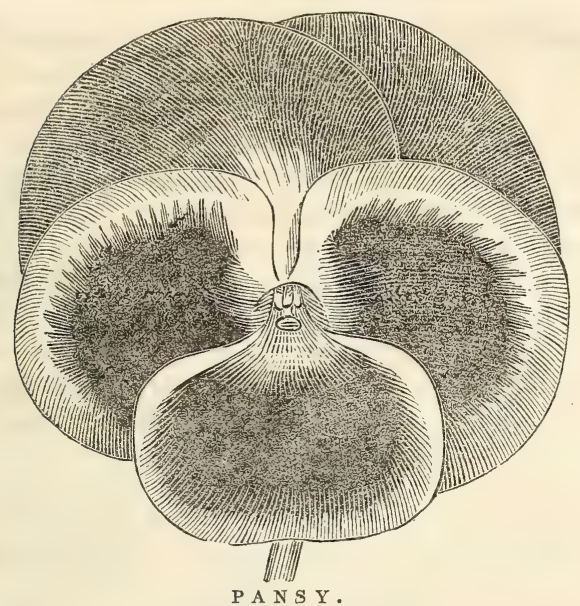

h.h.p. PENTSTEMON, choice mixed varieties.

PETUNIAS, splendid hybrid varieties.

PETUNIAS, BUCHANAN'S, new hybrid blotched varieties, beautiful, 25c

PHLOX DRUMMONDII, an indispensable plant for bedding, quite as

desirable as the Verbena. The following are very choice:Alba, pure white; Occulata, white, with dark eye; Louis Napoleon, brilliant scarlet; Leopoldina, pink; Radowitzi, dark rose, striped with white, a very fine and striking variety; Radowitzi Violacea, a new and distinct striped variety, $20 \mathrm{ets}$. h.l.*PINKS, EXTRA DOUBLE CHINA, picturesque colors, fine.

h.p. " Fine Garden, double and fine.

h.h.p. " PICOTEE, finest selected English, 25 cts.

PITCAIRNIA SPLENDENS. A splendid hot-house plant, with brilliant scarlet spikes of flowers, 50 cts.

h.p. POLYANTHUS, finest English varieties, 25 cts.

h.p. " " good mixed.

POLYGONUM ORIENTALE PUMILUM, FLO. RUBRA, new, 25 cts.

PORTULACA GRANDIFLORA FL. PL. VARIET. 8 finest double varieties of the most brilliant colors in scarlet, crimson, yellow, striped, etc. This proves to be quite an acquisition; flowers the past, season were perfectly double. In consequence of the difficulty of obtaining seeds of this novelty, the price per paper will still be, $\$ 1.00$.

RHODANTHE MANGLESII, pink-everlasting flower.

RHODANTHE MACULATA. Introduced from Australia. Differing from Rhodanthe Manglesii in being more robust, sometimes exceeding 2 feet in height, producing flower heads $1 \frac{1}{2}$ to 2 inches. The ray scales are of a bright rosy purple, the disk yellow, surrounded by a conspicuous crimson ring. First Class Novelty, $25 \mathrm{cts}$. 
RICINUS SANGUINEUS.- Showy and effective, growing from six to eight feet high, blood-red stalks and seed-pods.

" " TRICOLOR. Dark green and brown-spotted, the stalk is reddish-brown, $25 \mathrm{cts}$.

"AFRICANUS ALBIDUS, contrasts finely with the above.

SALPIGLOSSIS, neat and beautiful plants, suitable for pot-culture or the flower-border, blooming all summer.

SCHIZANTHUS GRANDIFLORUS OCCULATUS.-Elegant slenderbranched annual, grown in pots for the green-house.

SAPONARIA, of dwarf compact growth, profusion of bloom throughout summer and late autumn. The varieties are-Multiflora, rosy pink; Alba, pure white; Ocymoides, a perennial varietyone of the finest plants for covering rock work.

SCABIOSA NANA, dwarf, deep red and maroon.

SENECIO CUPREATA, FL. PL., bright copper color.

" ELEGANS, NANA. CERULEA FL. PL.-New dwarf double Jacobea, profuse flowering.

SPERGULA PILIFERA, recommended in England as a substitute for grass in the formation of lawns, grass-plats, \&c.

STATICE BONDUELLI, sulphur yellow flower.

STOCKS, (Cheiranthus Annus.)-Large flowering German Ten-Week.

" CRIMSON DWARF BOUQUET, fine, $20 \mathrm{cts}$.

" ROSE " " " 20 cts.

" VICTORIA, scarlet, 20 cts.

" SCARLET, intermediate, 10 cts.

"6 WHITE, " 10 cts.

The Stocks are all very fragrant, and rank among the most desirable of plants, either

for the Garden or Conservatory. For other varieties, see "German Flower Seeds."

SAPONARIA CALABRICA MARGINATA. Color rose and white, 25 cts.

SALVIA COCCINEA PUMILA. Attains half the height of Salvia Coccinea, very useful for groups, 20 ets.

h.b. SWEET WILLIAM, AURICULA FLOWERED.-Beautiful colors. " " NEW DARK.

TAGETES SIGNATA PUMILA, (VILMORIN.)-This is really an acquisition to our list of annuals-its dwarf habit, compact and bushy growth, with its densely covered, bright yellow flowers, must give it a prominent position, and prove valuable as well for borders as for beds, planted either by itself, or alternated with different colors, 20 ets.

c. THUNBERGIA, desirable climbing plants, constant bloomers; the most desirable are Alata, buff, dark eye; AlBa, white, dark eye; Aurantica, orange dark eye.

TRIFOLIUM ODORATUM, sweet scented clover, very fragrant.

c. TROPAOLUM PEREGRINUM, (Canary-bird flower,) with yellow canary-like flowers, a useful climbing plant. 
TROP EOLUM, TOM THUMB WHITE. Color cream, $20 \mathrm{cts}$.

66

varieties, Tom Thumb, dwarf.

VERBENA, seed saved from the finest named varieties, 25 cts.

" good mixed, assorted colors.

VERBENA AUBLETIA, reddish purple.

t.b.*VINCA ROSEA, and ALBA, ornamental and free blooming; fine for bedding out in summer; known as the Madagascar Periwinkle. VINCA ROSEA NOV. SPEC. Pure white without disk, constant variety, $20 \mathrm{cts}$.

h.p. VERONICA NEGLECTA, a hardy perennial plant, with spikes of blue flowers.

WALL-FLOWER, fine German, mixed.

"6 tall, double, brown rocket.

"6 double dwarf.

$p$. YUCCA FILAMENTOSA, Adam's Needle.

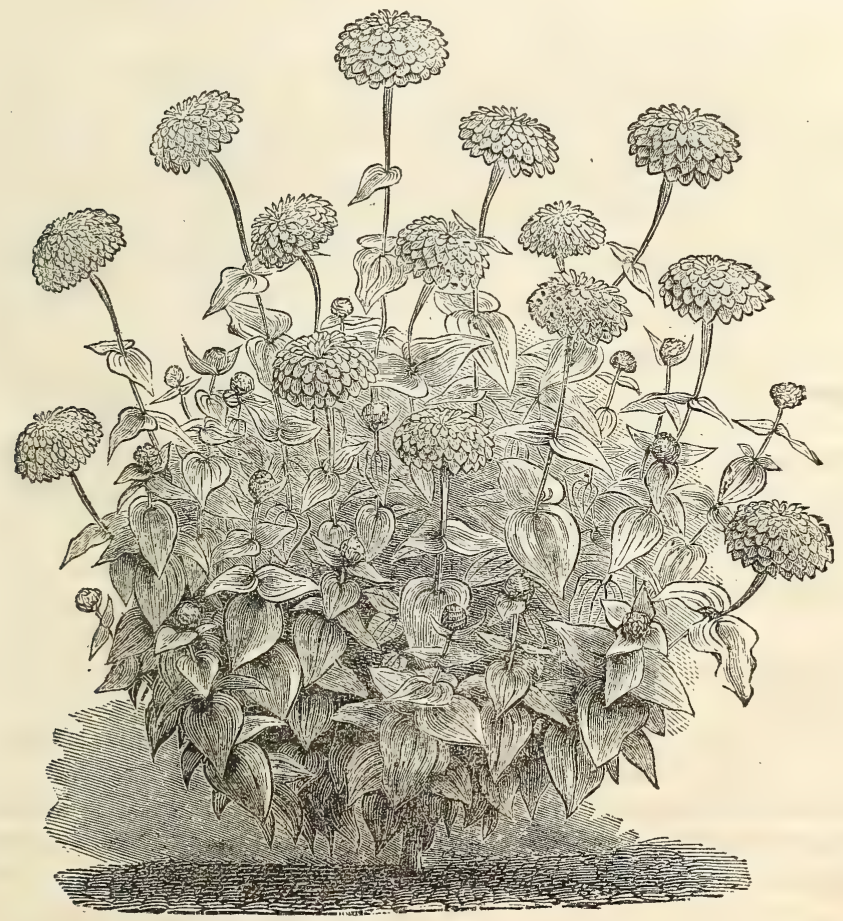

NEW DOUBLE ZINNIA ELEGANS. 
ZINNIA ELEGANS, FL. PL., DOUBLE ZINNIA.-This proves to be quite an acquisition to our list of annuals. Its splendid double flowers rivalling in beauty, size and form, moderate sized Dahlies. Seed saved from the best double flowers per paper, 20 cts. ZINNIA DOUBLE, saved from good flowers, 10 cts.

“SPECIES from Miexico, with bright yellow flowers, a desirable bedding plant.

\section{German Flower Seeds, in assortments.}

The following are imported direct from Prussia, and will be found very choice. They are sold in the original packages at the prices named.

Each variety or color separate in the package.

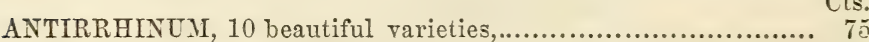

ASTERS, finest quilled, 24 varieties, .............................. 1.50

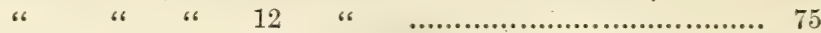

" Globe flowered, 12 " " $\quad$ "................................... 1.00

" Pyramidal, 12 " $12 \quad$................................... 1.00

“ DWARF BOUQUET, 12 varieties............................. 1.00

“ Truffauts P.EONIA FLORA, 12 rarieties,................... 1.50

“6 NEW IMBRIQUE POMPONE, 5 varieties,................. 50

" COCARDEAU, OR CROWN, 4 varieties,.................... 50

BALSAM, DOUBLE CAMIELLIA-FLOWERED, 12 varieties, ........ 1.50

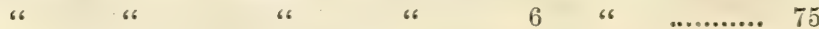

"

“ NEW FREXCH ROSE, 12 varieties,...................... 1.50

All the Asters, and Balsams, can be had in separate papers.

Price, per paper, $10 \mathrm{cts}$.

CARNATION, 12 varieties, ........................................... 2.00

COCKSCOMBS, fine German, 12 varieties, .......................... 1.00

IMMIORTELLE, or everlasting flower, 12 rarieties, ................. 1.00

HOLLYHOCKS, superb Double English 12 varieties,................ 1.00

LARKSPUR, HYACINTH FLOWERED, 12 varieties,.............. 75

“. CONSOLIDA, branching, 6 varieties, .................. 50

MARIGOLDS, fine Double, 12 varieties, ........................... 75

PINKS, 12 choice varieties, ........................................ 75

POPPY, Double Carnation, 16 varieties, ............................. 1.00

“. New Pæoniflower, 12 varieties,............................. 50

SENECIO ELEGANS, Double Jacobea, 5 varieties, .................. 50

SALPIGLOSSIS, 12 varieties, .......................................... 1.00

STOCKS, large flowered, Ten weeks, 12 varieties,................... 1.00

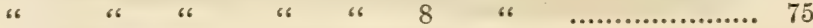

“ NEW LAVENDER-LEAVED, Ten weeks, 5 varieties, ... 50 
STOCKS, PERPETUAL FLOWERING, Ten Weeks, 10 varieties,.. 1.25

“ AUTUMNAL, 12 varieties, ............................... 1.25

“ EMPEROR, OR PERPETUAL, 6 varieties,.............. 75

“ BROMPTON, OR WINTER, 12 varieties,............... 1.00

All the above varieties of Stocks can be had in separate pa-

pers, colors mixed. Price, per paper, 10 cts.

WALL-FLOWER, fine German Double, 10 varieties, .................. 1.50

ZINNIA ELEGANS, 6 varieties, ................................. 50

GREEN HOUSE PLANTS, choice selection, 25 varieties, .......... 3.00

FERNS, 12 choice varieties, ....................................... 2.50

ORNAMENTAL-LEAVED PLANTS, 12 varieties,.................. 1.50

“ GOURDS " $\quad 25 \quad$ " $\quad$.................... 2.00

" GRASSES, 12 varieties, ............................... 1.00

PHLOX DRUMMONDII, 6 varieties, ............................... 50

PRIMULA CHINENSIS, 8 “ .................................. 2.00

PORTULACA, 6 varieties, ............................................ 30

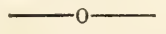

\section{Seeds of Green-house Plants.}

Florists' Flowers, ETc.-Those marked with a * are suitable for bedding out in the summer. Price, 25c. per paper, except where noted. Acacia, choice varieties.

Anomatheca Cruenta, (bulbous.)

Auricula, very choice imported.

Calceolaria, fine Hybrid varieties.

Calceolaria, superb spotted varieties, $50 \mathrm{cts}$.

Calceolaria rugosa, shrubby.

CALCEOLARIA HYBRIDA, NANA, GRANDIFLORA PRACOX,superb large flowers, of bright colors, free-blooming, $50 \mathrm{cts}$.

Cineraria, choice Hybrid and dwarf varieties.

" " " selected, 50 cts.

Conclinium Ianthinum.

Cyclamen Persicum and European.

*Erythrina Crista-galli, or Coral Plant.

Erythrina Arborea, scarlet coral tree.

Epacris, choice varieties.

*Geranium, fine scarlet varieties.

Geranium, apple scented.

Gloxinias, from named varieties.

*Heliotrope Peruvianum, $20 \mathrm{cts}$.

$\begin{array}{lll}* & \text { " } \quad \text { Triumph de Liege, } 20 \text { cts. } \\ \text { * } \quad \text { Voltaireanum, } 20 \text { cts. }\end{array}$

*Lantana, newest varieties-a fine bedding plant. 
Pelargonium, finest fancy and large-flowered.

PRIMULA SINENSIS, FIMBRIATA CERMESINA SPLENDENS.-

Very large flowers, bright velvet-like crimson. This new variety surpasses all other varieties of the Chinese Primrose by its brilliant colors, 50 cts.

Primula Sinensis, Rosea Fimbriata, fringed Chinese Primrose.

" " Alba Fimbriata, fringed Chinese Primrose.

" " $\quad$ Fimbriata Alba, Rubra Striata.

"6 " Erecta Superba, (Novelty,) - 50 cts.

Phaseolus Carracalla, a hot-house climber.

* Salvia, Splendens, scarlet sage.

" Coccinea Splendens, free-bloomer, 10 cts.

“ Patens, superb blue.

"Porphyrantha, dwarf, crimson, 10 cts.

Tropæolum, Lobbianum, Green-house climber,

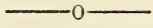

\section{General List of Flower Seeds,}

NOT INCLUDED UNDER OTHER HEADS.

Price, 5 cts. per paper, except where noted.

Aconitum, or Monk's Hood.

Adonis Miniata.

Ageratum Mexicanum.

Albiflorum.

Alonsoa grandiflora.

"Warscewiczii.

Agrostemma Coli rosea.

"flos Jovis.

Alstromeria, $10 \mathrm{cts}$.

Alyssum, sweet.

p. " Wiesbeckii.

Amaranthus Caudatus.

" Hypochondriacus.

" Giganteus.

" tri-color.

Ambrosia Mexicana.

Anagallis Indica, Pimpernell.

Aquilegia, Double Columbine.

“ Durandi.

“ Siberica.

Argemone albaflora.

“ Mexicana.
Asclepias Curassavica.

Antirrhinum, or Snap Dragon.

Asters, fine German, various.

Bartonia Aurea, golden.

Bracycome iberidifolia, blue.

Balsams, Lady Slippers.

Blitum Capitatum.

Browallia Elata, blue, 10 cts.

Calandrina, discolor,

Calandrina, elegans.

“ grandiflora.

“ umbellata, 10 ets.

Calceolaria Scabiosæfolia, 10 cts.

" Californica. "

Calendula, English Marigold.

Calliopsis Atkinsonii, (Coreopsis.)

" Coronata.

“ Nigra speciosa.

" Drummondii.

" Marmorata.

" Tinctorius.

Calliopsis, nigra nana. 
p. Campanula Pyramidalis, $10 \mathrm{cts}$. Clintonia, elegans, blue.
$\because \quad$ Carpatica.
" Loreii.
“ pulchella.

Candy Tuft, white rocket.

" purple "
" crimson "
" crown flowered.

Caterpillars, yellow. c.p. Clematis flamula.

Chrysanthemum, white.

Cleome grandiflora, Spider Plant.

Coix lachryma, Job's Tears.

Collinsia, bi-color. p. Canterbury Bells, mixed, single. Convolvulus, major, Morn'g-glory. $\begin{array}{lll}p & \text { " } ~ & \text { blue, double. } \\ \text { Cacalia coccinnea and aurea. } & \text { " tri-color. }\end{array}$

" " Alba.

" Marmorata.

“ Multicolor.

Commelina Cœlestis.

" Alba, white, $10 \mathrm{cts}$.

p. Cowslip, fine English.

Crepis, Hawkweed.

$$
\begin{array}{ll}
\text { “ } & \text { Silver. } \\
\text { “ } & \text { Purple. } \\
& \text { Yellow. }
\end{array}
$$

Cyanus, major and minor.

.6 new striped, 10 ets.

c. Cypress Vine, crimson.

$$
\text { " " white, } 10 \mathrm{cts} \text {. }
$$

Carthamus Tinctorius.

Catchfly, red and white.

Centauria Americana.

"Benedicta, Blessed Thistle.

"Moschata, Sweet Sultan. Celosia, Cockscomb.

"Macrocephala gigantea.

"Spicata rosea.

" crimson dwarf.

Centranthus Macrosiphon.

" Nanus, dwarf.

Chrysanthemum, tri-color.

$\begin{array}{ll}\text { “ } & \text { New Golden. } \\ \text { " } & \text { Venustum. } \\ & \text { Burridgeanum. }\end{array}$

Clarkia, integripetala.

“ Marginata.

" Nerieflora, double.

" elegans and pulchella.
Didiscus Coeruleus, 10 cts:

Delphinium Cardiopetalum.

" grandiflorum.

$p$. Delphinium, Barlowii.

p. " Hybridium.

h.p. Digitalis, Foxglove.

“ purple and white.

" new spotted.

" yellow, Rosea.

c. Eccremocarpus scaber, 10 cts.

Erodium Gruinum.

Eschscholzia, California Poppy.

" Alba, Tenufolia.

" Crocea, Californica.

Ethulia Corymbosa.

Eucnidia Bartonoides, 10 cts.

Eutoca Multiflora.

Euphorbia variegata.

Erysimum Peroffskianum.

Gaillardia picta.

$\begin{array}{ll}\text { “ } & \text { Aristata. } \\ \text { “ Josephus. } \\ \text { " Alba Marginata. }\end{array}$

Gillia Capitata, blue.

" " Alba, white.

" Tri-color, three-colored.

p. Gentiana Acaulis.

p. " " Asclepidea, 10 cts.

Godetia Rubicunda. 
Godetia Lepida.

“ Venosa.

Gourds, (Cucurbita.)

“ Egg-shaped.

"Bottle, or Calabash.

" Club-shaped.

" Mock Orange.

Gypsophila elegans.

c. Hyacinth Beans, dark purple. p. Linum Lewisii.

c. Loasa Aurantiaca, 10 cts.

h.p. Lobelia Cardinalis.

" Erinus.

" Marmorata.

" Ramosa.

"Gracilis erecta, 10 cts.

c. Lophospermum Scandens $10 \mathrm{cts}$.

c. " Hendersonii, 10 cts.

c. " " white flowered. Lotus Jacobæus.

h.p. Honeysuckle Chinese evergreen. Lupinus, mixed.

Helianthus, Sun-flower.

\section{" Californian. \\ " Nana, dwarf. \\ “ Green centered.}

p. Hesperis Matronalis, Sweet.

$$
\begin{array}{ll}
\text { ‘6 } & \text { Rocket. } \\
\text { “ } & \text { Tristis. }
\end{array}
$$

Hibiscus Thunbergia.

" Africanus.

h.p. " palustris.

Iberis, see Candytuft.

Ice Plant, Mesembryanthemum. Inopsidium acaule.

c. Ipomæa Burridgii, crimson.

c. " Coccinnea, scarlet.

c. " Nil, sky-blue.

c. " Limbata, 10 cts.

c. " Michauxii.

c. " Hederacea, ivy-leafed.

b. Ipomopsis elegans, scarlet.

" Alba striata.

Kaulfussia Amelloides.

$$
\text { “ Rosea. }
$$

Larkspur, Dwarf rocket.

" hyacinth flowered.

p. “ Bee.

Leptosiphon Androsaceus.

" $\quad$ Aureum.

Limnanthes Douglassii.

Lisianthus Russelianus.

h.p. Linari Perezi.
"Cruikshankii, variegated.

" Hartwegii.

" Hybridus.

“ Dunnettii.

"Subcarnosus.

، Sulphureus.

"Tri-color.

p. Lychnis Albus, white.

p. " " Chalcedonica.

$p$. " "Dwarf rose.

Mathiola or ten week stock.

Malcomia, bi-color.

Malope, trifidia.

" Albiflora, white.

" Grandiflora.

Martynia, fragrans.

Marigold, Dwarf French.

Mesembryanthemum.

$\begin{array}{ll}\text { " } & \text { Album white. } \\ \text { " } & \text { Ice Plant. } \\ \text { " } & \text { Tribrum, Dew. }\end{array}$

Mignonette, sweet scented.

" large flowering.

Mirabilis jalapa, Marvel of Peru.

" Pigmy dwarf.

" Large African.

" Ranunculus.

Nasturtium, dark erimson.

"dwarf, crimson.

" " scarlet.

Nemesia floribunda. 
Nemesia Compacta, elegans. Nemophilla, or Grove Love.

$\begin{array}{ll}\text { “ } & \text { Discoidalis. } \\ \text { “ } & \text { Macignis, blue. } \\ \text { “ } & \text { Marginata. }\end{array}$

Nicotiana Tabacum.

Nigella Damascena.

$$
\text { "6 "N Nana. }
$$

Nolana prostrata.

$$
\text { “ Alba. }
$$

Nyctarina Capensis.

Obeliscaria Pulcherima.

h.p. *Enothera Grandiflora.

" Bistorta Veitcheana.

" Drummondii.

66

$6 \quad$ Nana.

Palafoxia texana.

Papaver, or Poppy.

“ Carnation Poppy.

" Double White.

" Involucratum maximum.

" Oriental.

"Ranunculus.

“Somniferum, opsium.

$p$. Penstemon, fine mixed, $10 \mathrm{cts}$.

Perilla Nankinensis.

Petunia, Purple.

"White.

Phacelia Congesta.

c. Phaseolus Multiflora.

$p$. Pinks, Pheasant's Eye.

p. " Belgian.

p. " Mountain.

b. " Red Japan.

b. " China, or Indian.

Phlox Drummondii.

Platystemon Californisum.

Podolipis Gracilis.

Pomegranate Melon.

h.p. Potentilla, mixed.

Portulaca, white, scarlet, crimson.

Portulaca, yellow, orange, striped. Virginian Stock, red and white.

Pyrethrum Roseum.

Salpiglossis picta.

" yellow.

" coccinnea.

Solanum texanum.

Scabiosa Major.

c. Scarlet Runner Bean.

Shortia Californica.

$p$. Sweet William.

$p$. Sweet William, new dark.

Schizanthus, pinnatus.

$\begin{array}{ll}\text { “ } & \text { Grahamii. } \\ \text { " } & \text { Grandiflora oculatus. } \\ \text { " } & \text { Priestii. } \\ \text { " } & \text { Venustus. }\end{array}$

Scorzen tingitana.

$t$. Sensitive Plant.

Senecio elegans, Jacobea.

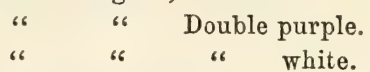

Silene Pseudo Atocion.

“ Pendula Alba.

"Regia.

- Rubella Alba.

$S_{w}$ eet Peas, Painted Lady.

" Everlasting.

“ Scarlet Tangier.

" mixed.

c. Thunbergia Alata.

c. "s Alba.

c. " Aurantiaca.

c. " " Bakerii.

c. " mixed.

Tournefortia, Summer Heliotrope.

Trifolium Aurantiacum.

$h . p$. Valeriana, red and white.

Venus Looking Glass.

$h b$. Verbascum Phœnicium.

$t$. $p$. Veronica Syriaca.

Viscaria Occulata.

Nana. 
Violet Russian, 10 cts. "Sweet, 10 ets. Wallfower blood red. “ single.

Whitlavia Grandiflora, blue.
Zinnia, elegans.

" bright scarlet.

" eight colors mixed.

" white.

" yellow.

\section{Ornamental Grasses. FOR BOUQUETS AND DECORATIVE GROUPS.}

Agrostis Pulchella.

" Nebulosa.

Arundo Donax versicolor,

(Ribbon Grass.)

Avena Sensitiva or Animated Oats.

Briza Maxima, Quaking Grass.

" Gracilis.

Coix Lachryma.

Elymus Hystrix.

Eragrostis Elegans. (Love Grass)
Eragrostis Namaquensis.

$$
\text { " Senegalensis. }
$$

Grangea Maderaspatana.

Gynerium argenteum.

(Pampas Grass,) 25 cts.

Lamarkia Aurea.

Sorghum Saccharatum.

Sorghum Bi-color.

Stipa Pinnata, Feather Grass.

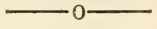

\section{Everlasting Flowers.}

Price, 5 Cts. per p per, except where noted.

These are desirable for maki $\mathrm{g}$ up Winter Bouquets and Wreaths. They should be cut when in perfection, and dried slowly in the shade.

Acroclinium Roseum, 10 cts.

“ Album, $10 \mathrm{cts}$.

Ammobium Alatum.

Gnaphalium Fœtidum.

Gomphrena Globosa, Purple.

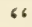

“

“

Alba.

Orange. Striped.

Helichrysum Album.

Helichrysum Lucidum.

Helichrysum Macranthum, $10 \mathrm{cts}$.

- Polycolymna Stuartii.

Rhodanthe Manglesii.

Statice Bonduelli.

"Sinuata.

Xeranthemum, purple. " white. " jellow.

\section{$-0-$}

\section{Bedding Plants and Florists' Flowers.}

BEDDING PLANTS are such as are suitable for planting in the open border or flower garden in early summer to bloom till frost; they are then taken up and housed, or cuttings obtained from them for next seasion's planting. 
FLORISTS' FLOWERS are those of which there are many Hybrid varieties, annually increased or improved. Of these, the Dahlia is one of the most popular.

\section{THE D A H I I .}

Of this attractive flower we have several bundred varieties, and are constantly adding all the newest and best as they are offered, and rejecting older and inferior kinds. Our collection received the First Premium at the Pennsylvania Horticultural Society's Exhibition, Sept., 1863.

Dahlias delight in a rich sandy loam, highly manured with decomposed cow-manure. To insure perfect flowers, mulch during the summer with short manure. Thin out superfluous branches, and keep them well tied up to strong stakes, firmly driven in the ground at the time of planting. The best time for planting is about the first of June, and the roots can be preserved during the winter in dry sand, free from frost, damp, or fire heat.

The following twelve varieties have been selected as among the best of the recent introductions, and were among the stand of flowers which received the First Premium.

Strong plants will be ready to send out by the 1st. of May.

Twelve first class Dahlias price $50 \mathrm{cts}$. each or five dollars per dozen. Aihlete.-Rosy lilac fine.

Celine.-Maroon purple, extra large.

Charivari--Yellow, striped and dotted carmine.

Duke of Wellington.-Maroon edged with deep rose.

Ebene.-purplish carmine, fine.

Mad'lle Dardenne.-Pale flesh with yellow centre.

Madam Berreaud.-Orange scarlet.

Madam Mezard.-Lilac, profusely striped with deep crimson.

Oblata.-Pure white, very double and fine.

Ophelia.-White, shaded yellow, and striped with scarlet.

Wacht am Rhein.--Dark maroon in the centre, shading off to carmine and pale rose, and frequently nearly white at the tip of petals.

Victor de Magenta.-Yellow, slightly tipped with rosy salmon.

The following twenty sorts are offered as a good selection, and can be supplied either in dry roots or plants, at the option of the purchaser. Price 30 cents each. $\$ 3.00$ per dozen.

Ariana.-Lilac, globular form, superb.

Beauty of the Grove.-Buff, edged with crimson.

Carminata Striata.-Blush, striped with crimson.

Crepuscula.-Orange red. 
Col. Backer.-Clear sulphur yellow.

Duchess of Wellington.-Creamy yellow, dwarf.

Fanny Dodd.-Pure white.

Grand Duke Nicolaiewitch.-Brilliant carmine.

Joshua Longstreth.-Unsurpassed rosy lilac, large.

Kossack.-Dark scarlet, fine.

King of Dahlias. -Lilac shaded with crimson, superb.

Lady Cathcart.-White, tipped with delicate lilac.

Monseigneur Sibour.-Peach lilac, extra fine.

Mrs, Turner.-Fawn color, with yellow at the base of the petals, novel.

Madam de St. Laurent._Light crimson, mottled and striped with white. Othello.-Dark purple.

Oeillet Parfait.- Yellow, striped with scarlet, dwarf.

Roi du Portugal.-Scarlet, globular form.

Reine de Prusse.-White, edged with dark maroon.

Triumph de Roubaix.-Amber, shaded with rose and tipped with white.

\section{LILIPUTIN OR ROUQUET DAHLIAS.}

This novel section includes a class of varieties distinguished by a profusion of elegant miniature blossoms, remarkable for their symmetry of form and beauty of colors. They will be found useful in forming Bouquets, Baskets or Vases of cut flowers.

\section{Price of Plants, 30 cents each, $\$ 3$ per dozen.}

A limited number of roots can be furnished on early application. Auerbach.-Orange, with bronze shade.

Deutscher Goldfink.-Golden-yellow with orange-red tip, extra.

Dr. Schwebbes.-Deep Scarlet.

Damen-Roeschen.-Beautiful rose.

Gretchen Von Dieskau.-Buff, tipped with white.

Grenoble.-Bright carmine.

Gruss an Zwickau.-Blood-red.

Hertha Von Bonin.-Purplish-violet on white ground.

Kleine Braut.-White, tipped with carmine.

"Elsternixe.-Pale rose.

Kleiner Gerngross. - White, shaded with lilac.

" Gotthold.-Rose, shaded with purple.

"Hermann.

Kleines Goldlicht.-Yellow, with scarlet.

Kind der Treue.-Pale rose, white centre.

Othello.-Dark maroon.

Racine.-Maroon. 


\section{THE VERB E A .}

The Verbena is now our most useful and popular bedding plant; yet for want of the proper soil, ma $L_{2}$ fail to grow it to perfection. Frequent change of soil is necessary. A fresh, sandy loam, enriched with well-rotted manure, or sods from a pa ture-field, thrown up with cow manure, and well-rotted before using, we have found the best. A simple plan, when it is not practicable to renew the entire bed, is to dig holes about one foot square and deep, wherever a plant is desired, and fill up with fresh soil, as above named.

If a fine Fall bloom of the Verbena is desired, it will be necessary to make a second planting about the beginning of August; plants for this purpose may be obtained by layering shoots in small pots, sunk in the ground along side the parent plant, and watered daily in dry weather; they will be ready for transplanting in about three weeks.

We herewith give a list of the most choice new varieties. Those marked with a (D) are our own seedlings.

\section{List No. 1. $\$ 2.00$ per dozen. 25 cents each.}

Admiral Farragut, (D.)-Blood-red, white eye.

Belmont Beauty, (D.)-White, flaked with purple.

BuUe Benutr.-Deep bluish purple, white eye.

BeLla.-Fine rose, large.

Dazzle.--Light scarlet, with crimson eye.

Decorator.-Brilliant scarlet, white eye.

Gen'I. Rosecrans, (D. )-Rosy scarlet, white eye.

" Grant, (D.)-White, striped with blue, extra.

Inimitable.-Light bluish violet, white eye.

SNowwreath.-Pure white, free grower.

Star of the Union.-White and lavender blue, cross.

The Bride, (D.)-Blush-white, large and fine form.

List No. 2. $\$ 1.50$ per dozen. 15 cents each. $\$ 1.00$ per dozen without names.

BACCHUS,-Dark maroon, white eye.

BeLLe of Hartford.-Violet purple, white eye.

Butsuivg Bride.-Blush, crimson centre.

GLORIE DE VAISE.-Brilliant scarlet, purple centre.

Hon. Mrss Neville.-Deep violet-purple.

IsaAc Buchanan.-Bluish lilac, very fragrant.

Ivanhoz.-Rosy scarlet, white eye.

Mrs. Woodrufr.-Brilliant scarlet, large and fine.

Solferino, (D.)-Rosy carmine, lemon eye.

Thetis.-Violet blue, white eye.

Purity.-Pure white.

VIvid, (D.)—Scarlet, white eye. 


\section{DOUBLE PETUNIAS.}

\section{0 conts each. $\$ 1.00$ for the Sir.}

Double Petunias are among the recent novelties. They are not as robust as the single varieties, but answer quite well for bedding out. The following are the best:

Crimson Perfection.-Crimson. Beauty.--Rosy carmine, white stripe. Gen'l M'Clellan.-Purple, blotched Wm. Rollison.--Rose.

with white.

Madam Miellez.-Large white.

Van Houtii.-Rosy purple.

\section{SINGLE PETUNIAS. \\ 20 cents each. $\$ 1.00$ for the six.}

Buchanan's New Blotched Hybrid.

Forget-me-Not, (D.)-Amaranth rose, striped with white.

Prince of Wales.-Deep crimson.

Purpurea Marginata, (D.)-Purple, edged with white.

Union, (D.)-Brilliant erimson, flaked and striped with white.

Zouave.-Deep crimson, blotched with white.

\section{A N T A N A S.}

$\$ 2.00$ per dozen. 20 cents each.

This is a plant of easy cultivation, free-blooming, and well adapted for either bedding or pot-culture, withstanding extremes of heat and drought.

Alba Grandiflora.-White.

Lutea Superba.-Sulphur.

Crocea Superba.-Orange. Snowball.-White.

Grand Sultan.-Scarlet.

Comtesse Morny._Blush and rose.

Gigantea.-Purple and yellow.

Dr. Demange-Buff yellow and rose.

Fillonii.-Yellow, bordered with purple.

Surpasse l'Abbe Trouvais. -Lilac, bordered with yellow.

Celestina Philomele.-Orange yellow.

Garibaldi.-Lilac.

Fulgens Mutabalis.-Scarlet.

Mirabilis.-Beautiful orange.

\section{H E L I O T R O P E S.}

\section{$\$ 1.50$ per dozen. 15 cents each.}

The Heliotrope is a universal favorite. No boquet is considered perfect without it. It is a constant bloomer-blooming alike freely in the summer as a bedding plant, or in pots during the winter in the green-house. 
Grandiflorum.-Pale lilac. Gem.-Dark-bluish lilac.
Beauty of the Boudoir.-Bluish lilac, dwarf.

Souvenir de Liege.-Lilac and white. Belle of Jersey City.--Lilac, dwarf. Voltaireanum.-Bluish purple. Jean Mesmer.-Bluish lavender. Acubrefolia.-Variegated foliage, 25 cents. Petit Negress.-Dark purple, dwarf.

\section{Z ONALE GERANIUMS.}

These are commonly called "Scarlet" or "Horse Shoe Geraniums," on account of the peculiar mark on the foliage of many of the plants. For beauty, brilliancy, and continued bloom, they cannot be excelled; they are among our most desirable bedding plants. The following can be recommended. Price $\$ 1.00$ for the six.

Auber Henderson..-Blush white. Cerise Unique.-Cherry. Bishop Stowe.-Scarlet, fine foliage. Kingsbury Pet._Salmon. Hendersonii._Pure white. Vivid.-Scarlet, white eye.

\section{VARIEGATED-LEAVED GERANIUMS.}

25 to 50 cents each.

Flower of the Day.-Scarlet flowers, white edged foliage. Alma.-Fine scarlet flowers, white edged foliage. Henders nii.-Large scarlet flower, pure white edge. Countess of Warwick.-Cherry flower, fuliage white edged. Manglesii.-A hybrid variety, foliage white, variegater. Culford Beauty.-Foliage variegated with white, and stained with faint purple.

\section{HYBRID BEDDING AND SCENTED LEAF GERANIUMS.}

20 cents each; $\$ 2.00$ per dozen, except when otherwise priced. Capitatum.--Rose-scented.

" - Major, pretty cut leaf, highly scented.

Lady Plymouth.-Variegated Rose Geranium, $50 \mathrm{cts}$.

Denticulatum. - Large cut leaf, rose-scented.

Odoratissimum.-Apple-scented, spicy apple perfume, $25 \mathrm{cts}$.

" -Erectum, or nutmeg-scented.

Quercifolium Eximium.-Oak-leaved.

Ivy-leaved-Pretty trailing var.

Tomentosum.-Velvety leaves, strong perfume of Peppermint, $25 \mathrm{cts}$. Shrubland Pet.-Dwarf, sweet-scented var.

\section{G A Z A N I SPLENDENS.}

Conspicuously beautiful on account of the unusual size and brilliancy, and the richly contrasted colors of its flowers, added to its dwarf and compact yet free habit of growth. 20 cents each. 


\title{
ERYTHRINA CRISTæ-GALLI,
}

\author{
OR CORAL PLANT.
}

A magnificent plant, producing its erimson pea-shaped flowers on spikes eighteen inches long. Plant them in the garden in May, and they will flower profusely three or four times in the course of the summer. They may be taken up in the fall, and kept in perfect preservation during winter, in a dry cellar, the roots covered with half-dry earth. When taken up, the branches should be well cut back. We have a large plant, which has been treated in this manner for the last ten years. Price, from $50 \mathrm{cts}$, to $\$ 1.00$ each, according to size.

\section{IOCHROMA WARSCEWICZI.}

A desirable green-house plant, suitable for bedding, with long tubeshaped flowers, of a bluish-purple color, blooming freely throughout the whole year. Price, 25 cts. each.

\section{THE PAMPAS GRASS.-(Gynerium Argenteum.)}

The most magnificent of Grasses, with long terminal silvery plumes, throughout the late summer and autumn months. With some protection it has stood the winters near Philadelphia; but it is safer to lift it in the autumn. 25 to $50 \mathrm{cts}$. each.

\section{TRITOMA UVARIA.}

A splendid half-hardy summer and autumn flowering plant, with stately fiower-scapes and magnificent terminal dense spikes of rich orange-red flower-tubes. They may be taken up in the fall and potted, and placed in a cool green-house, pit, or cellar. 50 cts.

\section{PANSY OR HEART'S EASE.}

We have an unrivalled collection, which has received the first prize from the Pennsylvania Horticultural Society for six years in succession.

Extra fine plants, in pots, . . . per dozen, \$2.00

Second choice, . . . . . . " . 1.25

\section{SALVIA S,}

Are all more cr less desirable for bedding purposes, as well as for green-house culture.

Splendens.-(Scarlet Sage,) $\$ 1.50$ per doz. . . $\quad$ each, 15 cts

Splendens Gordonii.-Dwarf, scâ̂let, . . . . “ “ 25

Patens.-Large azure-blue, free bloomer, . . • " “ 20

Tri-color.-Three colored, neat and pretty, . . " “ 20

Coccinnea Splendens._Scarlet, free bloomer, . • “ “ 20

Gesneriflora.-Rosy scarlet, . . . . . . " 25

Rosea.-Rose-colored, ... . . . . . . . 4 25 


\section{Miscellaneous Summer Beddiag Plants.}

Free bloomers, desirable for flower-borders. Those marked * are bardy.

Aloysia Citriodora, or lemon-scented verbena, each........... .20 *Antirrhinum, or Snap-dragon, 12 splendid varieties, per doz.....\$1.50 Ageratum Mexicanum, light blue.................................. 1.00

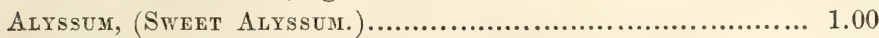

" Follis Variegata, pretty variegated foliage............ 1.50

Amarantuus, sp., very pretty, foliage red, yellow and green..... 1.50

*Bellis Perennis, (Daisy,) double crimson, pink and white..... 1.00 Cuphea Platycentra, scarlet flowering, dwf. compact habit..... 1.50 Canna Indica, Indian shot plant, scarlet......................each, $\quad .20$ Canna Warscewiczi, deep blood red......................... " 20 Carnations, tree or monthly, a splendid collection........... " 3.00 Farfugium Grande, variegated foliage....................... ، .25

Feverfew, double white daisy-like flower................per dozen, 1.50

Gaillardia Picta, orange and crimson.................... "6 1.00

Lobelia Erinus Speciosa, bright blue, pretty............ " " $\quad 1.50$

Mignonette, large flowering, sweet-scented.............. " ، 1.50

Minulus, or monkey flower.....................................each, . 15

" Moschatus, Musk plant.......................... " $\quad .6$

Nasturtidm, true Tom Thumb.............................. « $\quad .15$

Nierembergia Gracilis, lilac, free bloomer.............per dozen, 1.00 *Pinks, Laura Wilmer, white, maroon, centre.......... " " 1.50

Phlox Drummondi, choice varieties....................... 6 1.00

Petunias, finest mixed varieties.......................... 6 $\quad 1.50$

- Plumbago Capensis, clusters of pale blue flowers.............each, .25

" LaRpente, clusters of deep blue flowers.......... " . 20

*Primula Veris, or English Polyanthos.................per dozen, 1.50

*Veronica Neglecta, fine blue.................................each, .25

* " " Variegata, variegated foliage................... ، . . 25

Verbenas, good varieties without names................per dozen, 1.00

Vinca Rosea, and Alba, Periwinkle..........................each, . .15

NEW DOUBLE PORTULACA, Plants of this novelty true from cuttings, each......................... 25

\section{SUMMER CLIMBERS.}

\section{Siz Varieties for $\$ 1.00$.}

These are very useful for temporary decoration, growing luxuriantly during the season, and well adapted for clothing unsightly places. COBE SCANDENS...Large purple, bell-shaped flowers, of vigorous growth; price 20 to 50 cents each, acoording to sizo. 
IPOMEE A LEARII...Large bright blue, 20 cents. LOPHOSPERMCM HENDERSONII....Rose color. LOASA LATERITIA... Orange, star-shaped flower. MAURANDIAS, var...White, blue, pink, very graceful, rapid climbers. THUNBERGIAS, (of sorts, )... White, buff, and orange.

\section{- 0 \\ Hardy Herbaceous Plants.}

In addition to the varieties already enumerated, there is a large class of hardy plants, free blooming, suitable for the flower borders; indeed, they are indispensable to keep up a continuous bloom and rariety. Prominent among these are the

\section{CHR YSANTHEMUMS.}

\section{$\$ 2.00$ per dozen.}

This favorite autumn flower, since the addition of so many choice varieties, has become still more popular. The Dwarf or Pompone sorts are sufficient themselves to form a choice bouquet, such is the rariety of color and form embraced by them. The Pompones are particularly suited to pot-culture, while both large and dwarf are perfectly hardy, and form beautiful objects in the open garden.

\section{IARGE FLOWERING VARIETIES.}

AURORA...Fine yellow.

KENILWORTH...Lilac, yellow tip.• GLOIRE DE IIT. ROLGE...Orange. COQUETTE...Rosy blush. MAD. GUILLACIIE... Silvery rose. GOLDEI QUEEY OF ENGLAYD... AIME FERIERE....Silvery white.

Pale jellow, fine form.

ALARM...Rich crimson. REMUS...Bronzy red. COMPETITION....Pure white. HERHIONE...Blush. MT. ETNA...Large fiery red. TEMPLE OF SOLOMON...Yellow. M'LLE ELIZA VERDIER...Lilac.

\section{POMPONE OR LILIPUTIAN VARIETIES:}

SOLEIL D'OR....Golden yellow. BOB....Crimson.

DORIA...Orange yellow.

LOUISE HONARETI...Crimson on a yellow base.

FLEURETTE....Fine crimson.

LA FIANCE....Pure white.
FAVORITA... White, yellow centre. ZOE FEILLE...Rosy lilac and white ARIEL...Purplish lilac.

LAURA... Dark purplish crimson. THERESITA... Deep lilac. TRIAION... Yellow, crimson centre, dwarf. 
ASMODEUS...Fiery red.

ROI DE LILLIPUT...Maroon.

MISS TILTERED ...Early white.

COQUETTE...Deep rose.

MINIATURE...Orange red.

MAD. DE CASTLEBAJAC,

SOLFATERE...Light yellow.

RAGOZZA...Yellow, rosy tip.

Blush, yellow tip'd with lilac.

\section{PHLOX. \\ (Hardy Perennial.)}

The beauty of the Phlox is not yet sufficiently known and esteemed. For their brilliant trusses of flowers, comprising all shades of color, from white to crimson, striped and mottled, they have few, if any superiors among hardy perennial plants. They should be divided and replanted, in fresh prepared soil, each alternate year.

We have a large collection of all the finest new varieties. Price, 25 cents each. $\$ 2.50$ per dozen.

\section{PE N T E M O N S.}

The following varieties are among the finest thus far introduced. Price $\$ 1.00$ for the six. PURPUREA SUPERBA, MONS. PERRAS, VICTORY,
WILLIAM PFITZER, COMTE DE LAMBERTEYE, ISIS.

\section{DELPHINIUM FORMOSUM.}

\section{(Perennial Larkspur.)}

One of the finest, hardy herbaceous plants in cultivation, flowers in spikes of the most brilliant deep blue, marked by a white spot in the centre of each floret. They will flower, if not allowed to produce seed, from July to November. Price 15 cents each. $\$ 1.50$ per dozen.

DELPHINIUM MONS. MEUNER.-Differing from the above in being more dwarf, and a lighter shade of blue. Price 25 cents each.

\section{PRIMULA ACAULIS CANDIDISSIMA PLENA.}

\section{(Double White Primrose.)}

We have a few plants to offer this season of this favorite flower. It eucceeds best in a cold frame or cool green-house, and is now (January) in bloom. The flowers are very desirable for bouquets during the winter and spring months, being double and pure white. Price 50 cents each.

Primula Acaulis Lillacina Plena.-A double lilac, variety of the above. Price 50 cents each. 


\section{DOUBLE VIOLETS.}

\section{(Viola Odorata.)}

Another half hardy popular plant, grown extensively for bouquets. They succeed best in cold frames, well protected during the severe winter weather by mats and shutters. They will also flower freely in a cool green-house.

Neapolitan, light blue, large and fragrant...............per dozen, $\$ 1.50$

Imperatrice Eugenie, deep violet......................... " "

Double White.......................................... " " 1.50

\section{THE ROSE.}

The Rose still maintains its position as the most attractive of flowers. Every year adds a large number of varieties to our extended lists, new at least in name if not in character; and it shall be our especial endeavor, after careful comparisons, to point out such of them as show a decided improvement in their leading characteristics over pre-existing varieties.

Our collection of roses is now admitted to be one of the most complete, having been enriched, by direct importation, with the latest popular sorts. The repeated award of the highest premiums by the Pennsylvania Horticultural Society is sufficient evidence of their merit.

A few remarks, also, about budded, or, as they are commonly called, grafted roses, may not be out of place here. There exists a strong prejudice against them. Of course, it is not recommended to bud all kinds; but there are numerous splendid varieties which appear to thrive only when budded on a strong growing stock. Again : newly introduced varieties can, at first, rarely be obtained on their own roots. The greatest objection to budded roses is the "suckering" of the stock, which, if permitted to grow, naturally takes away the strength of the plant. When budded on the Manetta Rose, (which is the stock now generally used,) they can readily be distinguished by the pale green color of the leaves and the brownish-green of their stems, armed with formidable thorns; these should be cut away clean from the base of starting; for which purpose, the soil should be removed a little around the stem. There will be little trouble after the first season.

A fresh loamy soil, enriched with well-rotted cow-manure, we have found the best for roses.

EVER-BLOOMING ROSES cannot be secured unless the plants are kept in a vigorous, growing condition. To derive the greatest enjoy- 
ment from rose culture, beds should be prepared exclusively for their benefit, and their fertility preserved by yearly top-dressing with wellrotted manure.

Protection. Many of the most desirable of the free blooming roses, are liable to injury from severe winters, and are covered with straw, etc. to protect them from heavy frosts. The simplest and surest method is to bend down the stem, and peg them close to the ground, then draw the earth over them, so that they will be covered about one inch deep. Where they stand so close as to render it difficult to cover in this manner, additional soil or sand should be procured to effect a thorough protection.

Pruning is also very essential to insure a successful bloom from year to year. Without this care, the bushes will become feeble, stunted and enveloped in thick, half dead brush, and the flowers will be few and imperfect. With proper management, on the contrary, the plants may be kept healthy, vigorous, and afford yearly a profusion of fully developed and beautiful flowers.

The simplest form of training is in the form of a bush, as shown in fig. 1.

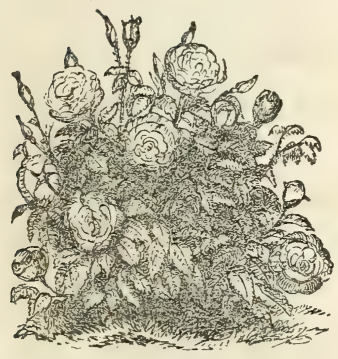

Fig. 1.

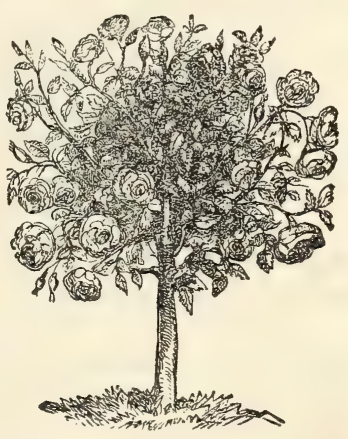

Fig. 2.

For the management of such, the chief requisites are the yearly application of old manure, cutting out old wood, and leaving the new and best shoots.

Tree, or Standard Roses, are greatly admired when well trained, but they require much care. A specimen is shown in figure 2. They are usually made by budding on vigorous standards, about two feet high. The buds, when growing, form the head. 
Pillar Roses can be formed by training strong growing varieties on the trunk of a small tree of cedar or other durable. wood, the branches being cut within eight or ten inches of the stem. Strong growing shoots are formed by first giving a strong root to the rose, by means of a rich soil and good culture, and then cutting back freely. Nothing can be finer than the effect produced by the blooming of a plant each of the Queen of Prairies and Baltimore Belle, both trained together on one pillar. Figure 3 is part of a rose-pillar, with the growth complete, and in full bloom.

Some of the Hybrid perpetual roses are, from their vigorous growth, delightful fragrance and free blooming qualities, admirably adapted for training as above; it is however only under good culture and management, that we would recommend them-the most suitable for this purpose are, Auguste Mie, Baronne Prevost, Lord Raglan, La Reine, Madam Laffay.

\section{SELECT NEW ROSES.}

H $\mathrm{Y}$ B I D, PER P E T U A I OR RE M ONTANT.

Altesse Imperial, fiery crimson, fine............................each,

Beauty of Waltham, bright, rosy crimson, cupped, large, vigorous

growth................................................each, $\$ 1.50$

Eugene Appert, rich dark crimson................................... 75

Emperor de Maroc, dark velvety maroon............................ $\quad 75$

General Washington, brilliant red, large, full and fine form........ 1.00

Henrietta Dubus, violet purple, shaded beautifully, imbricated... 1.00

Lord Elgin, dark purple, shaded with crimson..................... 75

Madam Charles Wood, vivid crimson, beautifully shaded with

purple, flowers of immense size................................. 1.00

Madam Charles Crapelet, cherry red, fine............................. 1.00

Madamoiselle Bonnaire, pure white, free............................. 1.00

Marechal Vaillant, purplish red, large and fine..................... 1.00

Reine des Violettes, violet purple, red centre......................... 1.00

Triumph d'Alencon, large red........................................ $\quad 75$

Victor Verdier, large, full carmine................................. $\quad 75$ 


\section{CHOICE OLDER VARIETIES.}

50 cents each. - $\$ 5.00$ per dozen.

Auguste Mie, large rose.

Baron Prevost, superb rose.

Cardinal Patrizzi, velvety crimson. Lion des Combats, dark red. Comte Bobrinsky, deep crimson.

Duchess of Orleans, pink.

Dr. Arnal, bright rosy red.

Eugene Sue, pale rese.

Geant des Battailies, scarlet.

Gen. Jacquiminot, crimson.

Jacques Lafitte, rosy carmine.

Jules Margottin, carmine.
Lane, light pink.

La Reine, large rose.

L'Enfant de Mt. Carmel, purple.

Lord Raglan, large crimson.

Mad. Laffay, dark red.

Mad. Rivers, pale rose.

Pæonia, crimson red, large.

Pius IX, erimson purple.

Prince Albert, dark erimson.

Prince Leon, rosy erimson.

Souvenir d'Levison Gower, dark rose.

Triomphe de L'Exposition, large red erimson.

BOURBON ROSES.-This class contains some of our choicest everblooming roses. They require but a slight protection. Price 25 to 50 cents each.

Empress Eugenie, pale rose.

Hermosa, pink.

Souvenir de Malmaison, blush.
Marquise de Balbiano, carmine.

Mad. Bosanquet, blush.

Sir Jos. Paxton, crimson.

BENGAL, CHINESE, or DAILY.-The brilliant colors of many roses of this class, as well as their constant blooming and dwarf habit, render them great favorites for window-gardening and winter-blooming; they are also equally adapted for the fiower-bed or pot-culture. The following six select sorts are the most desirable. Price 25 cents each :

Abbe Moiland, reddish purple.

Indica Alba, (White Daily.)

Archduke Charles, changeable.

Eugene Beauharnais, erimson.

Louis Philippe, crimson, rose

centre.

Pink Daily.

TEA SCENTED ROSES.-To the free blooming habit of the Bengal section, the Tea Scented Rose adds the delicious perfume which gives them their title. While they are not so hardy north of this latitude as the classes already noticed, if covered, they will stand the most severe winters. The following are desirable. Price 25 to $50 \mathrm{cts}$. each.

America, creamy zellow.

Bougere, blush pink.

Cels, blush, free bloomer.

Canary, yellow, 50c.

Devoniensis, creamy white.

Gloire de Dijon, blush and yellow. Souvenir d'un Amie, large rose.
Saffrano, saffron yellow.

Mad. Bravay, pure white,

“ Falcot, saffron, 50c.

“ Willermoz, white.

“ Damazin, blush, 50c. 
NOISETTE ROSES.-These roses are free-blooming, flower in clusters, of taller habit than the foregoing classes; some of them are very fragrant, and many of them are quite hardy, and adapted for training to trellisses and pillars. Six choice rarieties, $\$ 2.00$.

Amie Vibert, pure white.

Mad. Deslonchamps, blush.

Fellenberg, crimson.

Jacques Amyot, rosy lilac.
Jaun Desprez, rosy buff.

La Pactole, pale yellow.

Ophire, buff.

Phaloe, buff and rose.

\section{MOSS ROSES.}

50 cents each.

White Moss, in clusters. Princess Adelaide, rosy lilac. Lane, very large rose.
Etna, bright crimson.

Salet, rose, perpetual.

Mad. Ed. Ory, rosy crimson, perp'l.

\section{CLIMBING OR PILLAR ROSES.}

25 to 50 cents each.

Baltimore Belle, blush.

Queen of Prairie, deep pink.

Grerille, changeable.

Lady Byron, pink.

Lamarque, creamy white.
Monstrosa, pink.

Musk, cluster, white.

Thite Microphilla, waxy white.

Sir-Walter Scott, dark rose.

Gloire de Rosamene, scarlet.

\section{Summer Flowering Bulbs.}

The most prominent in this section are the rare and beautiful

\section{French Frbrict Gladiolns.}

They are the most stately and effectire of the whole genus; being of a robust erect growth. with green sword-shaped leaves and magnificent flower scapes, rising from three to five feet in height. The colors comprise the most brilliant of orange, scarlet, and rermillion tints upon yellow and orange grounds, including a graduated scale of intermediate shades, from, white with rosy blush and salmon rose tints, to a salmon-red and nankeen; from blush-white with purple crimson throat, and marginal streaks of pink, to light rosy-salmon grounds, with flakes of deep carmine. A succession of bloom may be had from July to September, by planting at interrals from April to June, reserring the strongest bulbs for the latest planting. Their culture is rery simple; they will grow in any ordinary garden-mould, but succeed best in good earth, manured with well-rotted horse-dung. The bulbs are taken up in the fall and placed in a dry cellar, protected from frost. 
ACHILLE...Currant red, white line in the middle of each division .each, $\$ 1.00$

ADONIS...Light rosy salmon, carmine margin....

ADELE SOUCHET... White-flamed rosy carmine....

AGLÆ...Bright-shaded salmon, large.

AM ABILIS...Vermillion, scarlet....

ANATOLE LEVANNEUR...Rosy violet, spotted with carmine

ARISTOTE...Light rose, purplish crimson stripes

BELLE GABRIELLE....Rosy lilac, flamed with bright rose, large, perfect form.

BERTHA RABOURDIN...Pure white, carmine stain.........

BRENCHILIENSIS... Very fine rich scarlet. ...

CUVIER...Crimson, flamed with purple, large flower, good form

CHATEAUBRIAND...Cherry red, light ground, sometimes variegated

CALENDULACEUS...Bright nankeen yellow.....

CERES...Pure white, stained with purplish rose, large and fine

CALYPSO...Rose, striped and blotehed with carmine........

CANARY...Clear yellow, shaded with rose.

CELINE....Pale rose, mottled with crimson, free flowering, and early....

CLEMENCE... White ground, richly feathered with rose and crimson flakes

COMTESSE DE BRESSON...Fine, rosy-tinted carmine and scarlet.

COURANTI FULGENS... Very rich dark crimson.

COITE. DE MORNY...Dark cherry, with white blotches.... DAPHNE...Light cherry, with dark stripes....

DE CANDOLLE...Light cherry, blazed with red...............

DIANE...White, flaked with dark red.........................

DOCTEUR ANDRY....Very bright orange, beautiful shape.. DON JUAN...Orange and fire-red.

DR. LINDLEY....Delicate rose, bright rose on the edge of petals, flamed with cherry, large and fine.

DUC DE MALAKOFF...Orange red, blazed with lighter stripes, white ground.

EDITH...Rose carnation, dark stripes, large.

EDULIA... White stained with violet, medium size, fine open 
EGERIE...Light orange-colored rose..... each

EL DORADO ...Pure Jellow, the inferior divisions striped with red, fine.

ERATO...Pale rose, carmine stains.

EUGENIE....Rosy salmon, rose stripe.

EUGENIE VERDIER.... White, violet stripe, fine.

FLORE...White, shaded with lilac rose, very large and distinet.

FANNY ROUGET...Flesh-colored rose.

GALATHE...Nearly white, with carmine stains. .

GOLIATH....Large, light red carmine.stains

HELENE...Lilac-tinged white, purple stripes................. HEBE...Salmon-tinted white, flaked with rose................ IMPERATRICE....Blush-white, striped with purple........... JAMES WATT...Light vermillion, large pure white stain,

striped with rose.............................................

JOHN WATERER....Cherry, blazed with red, white stain striped with rose, large and well-opened flower......... JEANNE D'ARC...White, tinged with rose....................

LE BARIOLE...Salmon, flaked and blotched with deep purple, dwarf.......................................................

LELIA...Peach blossom, stained with lilac......................

LOUIS VAN HOUTTE... Velvety carmine, spotted with purple.

LORD RAGLAX...Rosy salmon, vermillion spots

LE POUSSIN...Light red, white ground, and very large white stains on the inferior divisions.

MADAME HENRIQUE...Creamy white, Haked with purple,

MADAME RABOURDIN...Rose, flaked with carmine, and slightly lined with white in the centre of the petals....

MADAME ADELE SOUCHET... White, flaked with carminate rose

MADAIIE COUDER...Light carmine, shaded................. “

MADAME PAILLET...Carmine and violet......................

MADAIE BINDER ... White, carmine stripe, dwarf...........

MADAME EUGENE VERDIER...Deep cherry, bright purple stains.....

MARIA DUMORTIER... White, slightly streaked with rose and violet purple.

MAZEPPA...Orange rose, large yellow stains striped with rose............................................................

MARIE... White, stained with deep carmine, beautiful........ MATHILDE DE LANDVOISIN... White, carnation-tinted... MONS. BLOUET... Rose, shaded carmine 
NEPTUNE...Rosy carmine, violet centre.........................each

NAPOLEON III....Very bright scarlet, white streak........... “ .50 NINON DE L'ENCLOS...Blush mottled and striped with crimson.................................................... "6

ORACLE....Cherry rose, brilliant and fine.......................

OSIRIS... Dwarf, purple stained with white.....................

OPHIR...Dark yellow, purple stain.............................

OTHELLO...Light orange red, dwarf......................... “ “

PALLAS...Bright rose, striped with dark rose....................

PREMICES DE MONTROUGE...Brilliant, red, dwarf........ PELLONIA....Variegated rose, tinted with carmine............ PENELOPE...Large flower, white and carnation.............. PRINCE IMPERIAL... White, tinged with flesh color, large violet carmine stain

REBECCA...White, striped with lilac.........................

REINE VICTORIA...Pure white, violet carmine stain, large and fine.

RAPHAEL...Deep vermillion centre, lighted with white,... REMBRANDT ... Very bright deep scarlet...................... SOLFATERE...Deep sulphur yellow. STEPHENSON...Carminate cherry, with white lines, splendid spike, large flower, perfect shape.....................

SULFUREUS...Sulphur yellow, fine........................... TRIOMPHE DE ENGHIEN... Rich crimson, dwarf........... VESTA....Pure white, spotted with purplish carmine......... VULCAIN...Brilliant dark velvety crimson, purple shade... VICTOR VERDIER...Brilliant dark scarlet, crimson shade, VICOMTESS DE BELLEVAL....Carmine and violet.

\section{MISCELLANEOUS VARIETIES.}

AGAPANTHUS UMBEllatUS, (African Lilly.)....Blue, very showy ...............................................

AMARYLLIS FORMOSSISSIMA...Jacobean Lilly, rich crimson.................................................

GLADIOLUS GANDAVENSIS... Brilliant scarlet and orange-very effective when planted in beds and groups, 10 cents each; per dozen.

GLADIOLUS FLORABUNDUS...Blush, striped purplish crimson..................................................each,

OXALIS...Summer flowering; suitable for edging flowerborders. The varieties are-Lilacena, lilac ; Lasiandra, rosy crimson; Ambrose, pearly white; Speciosa, salmon red...............................................per dozen, 
TIGRIDIA PAVONIA...Red tiger flower. .50 “6 CONCHIFLORA... Shell flowered. ..per dozen, .50

TUBEROSE...Double. No garden is complete without this delightfully fragrant flower; it blooms in September, 10 cents each....................... MADEIRA or Mexican vine................10 cts. each,

\section{Fardy Spring Flowering Bulbs.}

In addition to the varieties already enumerated for the decoration of the Flower-Garden during the season, there still remains an extensive class of bulbous-rooted flowers, which are hardy, and require to be planted in the Autumn, to insure an early and perfect bloom during the Spring months. It is impossible to note the great variety that we can offer in this department. A large assortment is annually imported from Holland. They must be planted between the months of September and December. The principal varieties are,-

$\begin{array}{lcl}\text { Crocus, } & \text { Tulips, } & \text { Narcissus. } \\ \text { Hyacinths, } & \text { Lilies, } & \text { Crown Imperials. } \\ \text { Snow-drops, } & \text { Jonquils, } & \text { Lily of the Valitex } \\ \text { For prices and varieties, see } \text { Bulbous } & \text { Root } \text { Catalogue. }\end{array}$

\section{HARDY TUBEROUS-ROOTED PLANTS.}

In this class the PEONIA holds a prominent position. An immense number of new varieties have recently appeared in Europe. The following twelve are believed to be as distinct and desirable as any which are offered. Price, from 25 to $50 \mathrm{cts}$. each ; $\$ 4$ for the dozen.

Albaplena... White.

OfFICINALIS...Dark red.

Conte de Paris...Large rosy lilac. Potrsin...Very large, blush.

Edulis Superba... Rose \& salmon. Queen Victoria, large rosy blush. Fragrans...Dark rose, fragrant.

Humerr...Large Pink.

Mutabilis...Changeable.

Reevesir...Crimson purple.

Tenuifolia, crimson.

WhithexiI...White fragrant.

THE DIELYTRA SPECTABILIS is perhaps the most desirable and popular tuberous rooted plant. It is perfectly hardy, and is equally adapted to out-door planting, or forcing, for early spring blooming. It will produce its showy racemes of delicate pink and white heartshaped flowers from February to April in green-house; flowering in the open ground in May and June. 20 cts. each; $\$ 1.50$ per doz.

\section{JAPAN LILIES.}

Lilium lancifolium, these superb Lilies are perfectly hardy, flowering freely in August and September, forming one of the most striking 
object in the flower border; bulbs for fall planting can be furnished in the autumn, or in pots in the spring, they also flower finely in pots.
L. Lancifoliun, album, white,
L. " " 6 Punctatum, spotted,
L. " 6 RuBRum, white and red,
each, $75 \mathrm{cts}$
" 75
"6 75

\section{Green-house Plants.}

The distinction between green-house and hot-house is not so marked in our climate as it is in Europe. Our warm summers and bright winters enable us to cultivate successfully in the green-house many plants that are in Europe confined to the hot-house. Still we are convinced that in selecting plants, errors are frequently committed, and plants are purchased and placed in the green-house that are not capable of flourishing in the temperature there maintained, and much disappointment has, in consequence, been experienced. We, therefore, offer a brief list of such plants as will grow and flower in the green-house, where the temperature is not allowed to fall lower than 38 degrees at any time, but where it may be allowed to rise 75 or 80 degrees during the day, with bright sun. It may also be remarked, that the mode of management influences the heat required. Plants inured to dryness will stand a low temperature without injury, where the same plants, freely watered and kept in a damp atmosphere, would be severely hurt, if not destroyed.

\section{LIST OF GREEN-HOUSE PLANTS}

$\begin{array}{lll}\text { Abutilon, } & \text { Correas, } & \text { Lantanas } \\ \text { Acacias, } & \text { Coronillas, } & \text { Linums, } \\ \text { Azaleas, } & \text { Daphnes, } & \text { Pelargoniums, } \\ \text { Begonias, } & \text { Epacris, } & \text { Primulas, } \\ \text { Bouvardias, } & \text { Fuchsias, } & \text { Salvias, } \\ \text { Cactus, } & \text { Gardenias, } & \text { Stevia, } \\ \text { Calceolarias, } & \text { Jasminum, } & \text { Passiflora, } \\ \text { Camellias, } & \text { Habrothamnus, } & \text { Tropæolims, } \\ \text { Chorezemas, } & \text { Heliotropes, } & \text { Veronicas, } \\ \text { Cinnerarias, } & \text { Hetrocentrum Roseum, } & \text { Vincas. }\end{array}$

A selection made from the many varieties of the above will provide a fair amount of blossoms during the whole year.

\section{WINDOW GARDENING.}

We are indebted to Messrs. Luther Tucker \& Son, Albany N. Y. for the beautiful illustrations of Ward cases, and Plant cabinet or window case, which originally appeared in the Illustrated Annual Register for 1861 ; a work published annually by them, and for sale by us. Prico 25 cts.per copy. 


\section{Ward Cases.}

Those who have attempted to cultivate green-house plants in rooms, nare met with two serious drawbacks. One is the liability to become coated with

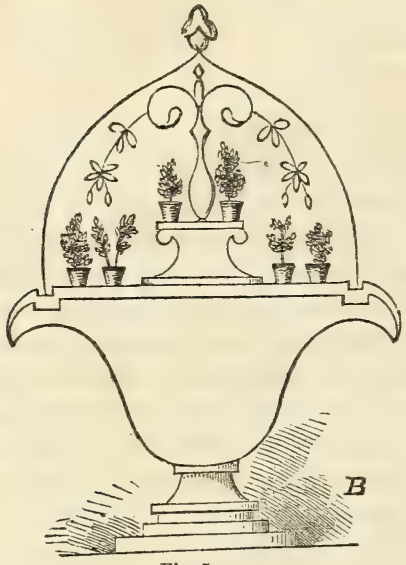

Fig. 5. dust, and the other is the dryness of the air, which is greatly increased by

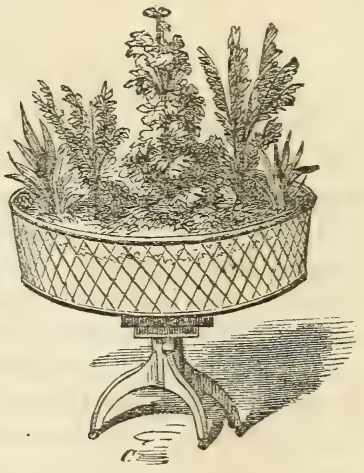

Fig. 6.

stove heat. For these reasons there are but few plants that will endure for a long time in common living rooms. To obriate these difficulties, the Ward Case has been constructed. It consists essentially in covering the plants with glass. This protects them from dust, and by confining the moisture which is constantly exhaled by the leaves, gives them a humid atmosphere. It also assists materially in equalizing the temperature, and shielding from the effects of the sudden changes which may occur in the room. For these reasons, the care of plants in these cases, is much diminished.

Fig. 5 represents the section of a small and simple case-made by covering a

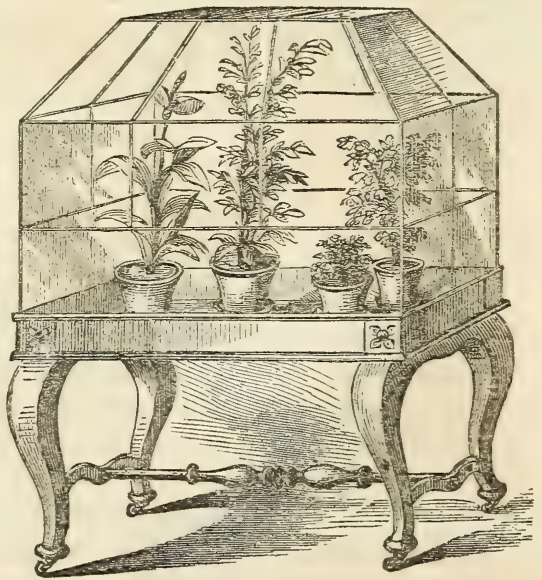

Fig. 7

Messrs. L. T. \& Son, also publish "The Country Gentleman," a weekly Journal for the Farm, Garden, and Fire-side, price $\$ 2$ per annum. 


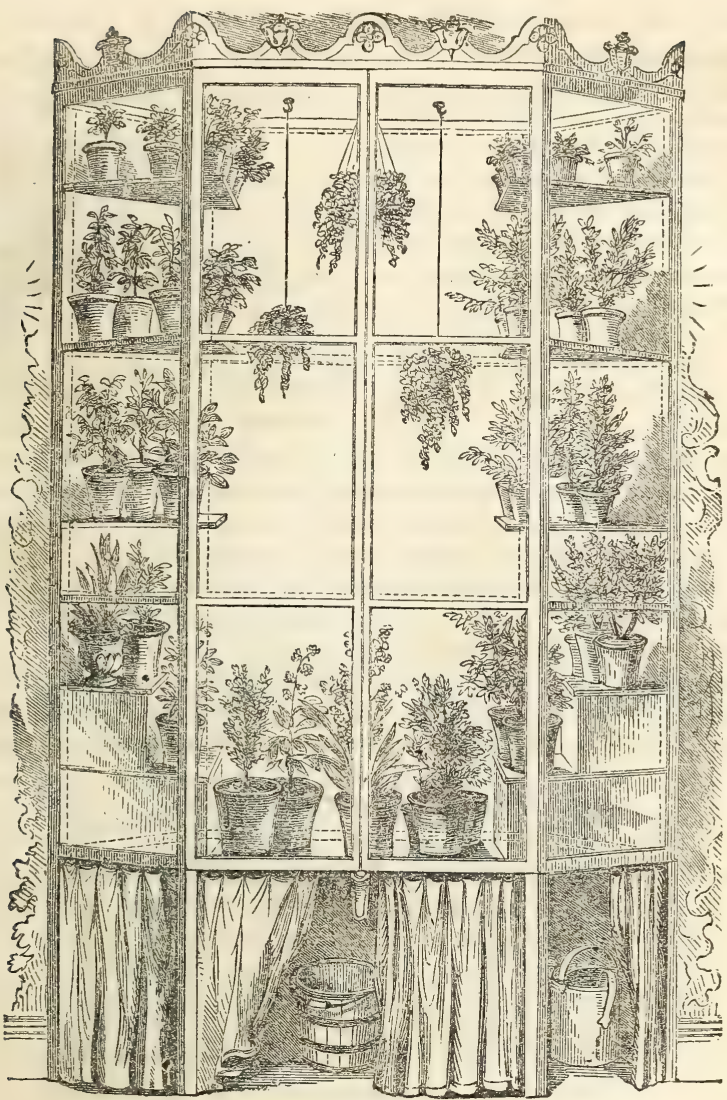

Fig. 9.

cast-iron vase of plants with a large bell glass. Fig. 6 is a cast-iron basket of plants, without the glass cover. Fig. 7 is the common Ward Case, attached to a table, and made about three feet long and two feet wide. The glass is nearly two feet high, besides the pyramidal cap.

A simpler and cheaper form of construction is shown in fig. 8, (on next page, ) which is made of wood, and covered with window sash. If well constructed and neatly kept, it will have a very ornamental appearance. When

The Gardner's Monthley, Edited by Thos. Meehan, the well known Horticulturist, Phila. published by W. G. P. Brinckloe, $\$ 1.50$ per annum. 
kept in a room subject to cccasional cold belor freezing, the proper temperature mar be maintained br the folloming contrirance. Let the pots stand on an iron or copper tray, (the pots being supported, if heavy, by iron bars, ) beneath which is soldered a convex round piece of sheet copper, so as to form a flat boiler beneath the tray. A tube through the tray above admits filling the boiler and allows the escape of the steam; a small tube and cock below allows the water to be dramn off. A lamp placed under the boiler, heats the water and keeps the plants sufficiently warm.

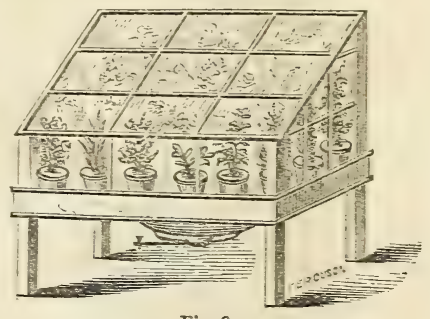

Fig. 8 ,

WixdoT CASE, (fig. 9.)-This is similar to the Mard Case, but is placed against a mindor, (a bar window being best,) and thus receires a strong light. It likemise occupies but little space. The shelres mar be so made that all the water thrown upon them, and orer the plants, br means of a stringe, runs dorn through the discharge pipe isito the pail. A pan nade of sheet zine turned up at the edges, and corering the floor under the case, serres to protect the floor from ant drip of water from abore.

AQTARIUM, (fig. 10.) - An interesting ornament for a library or cabinet, is a. water-tight glass case, supplied with water plants and fish. The water plants alone will not flourish, and the water becomes coated with green slime;

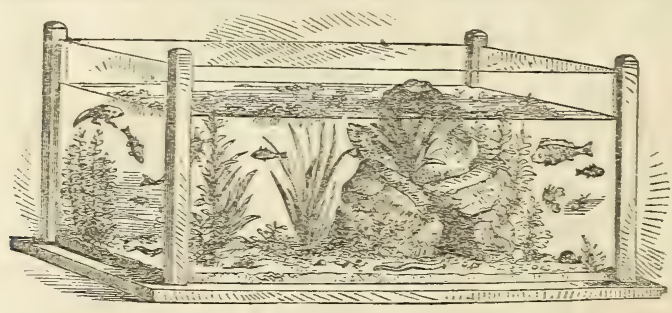

Fig. 10-AQtartor,

but the addition of minute shell-fish and oiher small aquatic animals, renders the water clear, and each cainses the other to thrire. Some skill and experience are necessary to adjust the proper number or quantity of each, for their best success

The Horticulturist. and Journal of Rural Art and Rural taste. New York; Mead and Woodward, \$2 per annum.

The Culturist, Philadelphia, A. M. Spangler Editor, an Agricultural and Horticultural Nonibly. 25 cents per annum, with a beautiful premium to every Subscriber. 


\section{F U C H S A S.}

Or, as they are popularly called, "LADY's EAR-DROP," constitute one of our most graceful tribe of plants. The Double Corolla varieties are of a more recent introduction. They all require a shady situation, and rich, loose, loamy soil, if bedded out.

Price 25 cts. each. $\$ 2.50$ per dozen. large plants 50 each.

A selection of twelve choice, single corolla varieties. Annie, (Banks) tube and sepals white, corolla deep rose. Catharine Hayes, scarlet sepals, light blue corolla. Empress Eugenie, scarlet, white corolla. Madam Lambert, very large amaranth, scarlet corolla. Mazeppa, blush tube, rosy salmon corolla. Leoline, erimson tube, large blush corolla, dwarf. Rose of Castile, blush white, carmine corolla. Scenator, large crimson tube, violet corolla. Schiller, tube greenish white, sepals white, corolla purple. Wiltshine Lass, waxy white tube, light violet corolla. White LADY, crimson, large white corolla.

\section{DOUBLE FUCHSIAS.}

Dud de Brabant, carmine sepals, dark bluish-black corolla. Dud de Trevise, crimson sepals, plum corolla. Maria Cornelirson, crimson sepals, white corolla. Murat, carmine, reflexed sepals, bluish black corolla. Маммотн, crimson tube, very large violet corolla, 50 ets. Mastadonte, immense flower of globular shape, deep erimson sepals, very dark corolla, 50 ets.

Maquis of Bristol, crimson sepals, purple corolla, fine habit. RogGier, carmine sepals, bluish lilac corolla. Sir Colin Campbelt, scarlet tube, dark purple corolla. Turban, scarlet sepals, plum colored corolla, fine, 50 cts. Universal, crimson sepals, dark corolla, compact habit, 50 ots, WASHington, scarlet tube and sepals, violet corolla.

\section{REMONTANT OR MONTHLY CARNATIONS.}

Very desirable for their free blooming qualities, during the Winter and early Spring months. Young plants, set out in the garden, will bloom profusely during the Summer months, and if lifted and potted in the Fall, will continue blooming the entire Winter. The following sorts can be recommended. 25 to $50 \mathrm{cts}$. each.

Albanis, bluph, scarlet stripe. Amanda Bertin, large satin rose. Bunker Hilu, large deep crimson. Erolle du Marie, purple and white. La Florifrere, purple maroon, La Purite, deep carmine.

striped with crimson.

Malmaison, French white.
Mon Triomphe, lilac, shaded with crimson. 


\section{COLEUS VERSCHAFFELTII.}

This has become one of our most popular Foliage plants. Although belonging to the Hot-house, it answers remarkably well for bedding out, this will no doubt, cause it to be unirersally grown. It is one of the most striking of all ornamental leared plants ; colors, crimson, green, and bronze. Price 25 cts. each, $\$ 2.50$ per doz.

\section{SHRUBBY CALCEOLARIAS.}

We have succeeded in raising several very superior varieties of this favorite plant, and which can be recommended for their robust habit, having withstood the excessire drought and heat of last summer remarkably well. They are suitable for pot culture or bedding out in shady borders.

\section{PRESIDENT LINCOLN,}

Broad, beautifully shaded foliage, with large trusses of large crimson

blossoms, robust habit, .............................................\$1:00

Mrs. Jay Cooke, large maroon and orange, fine,.................... 50

Eldorado, bright golden orange, very free,........................... 50

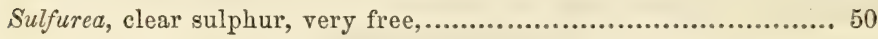

Hobby, bronze.

OLDER SORTS, 25 CTS.

Daniel O'Connell, bright yellow. Rugosx. Minor, yellow, large clusters.

\section{CISSUS DISCOLOR.}

We can recommend this as one of the most beautiful of our foliaged plants, and is particularly adapted, from its climbing habit, for twining around rustic and hanging baskets, during the Summer months. Price 25 to 50 ets. each, according to size.

\section{PELARGONIUIIS, OR FANCY GERANIUMS,}

Are considered among the most beautiful plants for green-house or room culture, easily grown, and presenting in their varied, as well as exquisite tints and pencilings, attractions which few other plants possess. We offer the following select list. Price, 25 to $50 \mathrm{cts}$. each.

Glorie de Paris.

Duke of Cornwals.

Butterfly.

JeNNY LiND.

King of the Belgians.

Medaille D'Or.
Mont Bianc.

Orion.

Perfection.

TourviLLe.

Village Maid.

Wilmer's SUPerb.

New Varreties, 50 to 75 ets. each.

Stephanie.

Stewart H. Lowe.

TAMBERLICK.
NAPOLEON III.

Rolisisonit.

White Flag. 


\section{HANGING BASKETS, VASES, ETC.}

The growing of plants in hanging-vases has become quite popular. They are made of various forms and material, from the common earthenware to the finest China and terra-cotta, ornamental and gilt; also of wire and rustic work, varying in price from fifty cents to five dollars each. The following plants are suited for planting in them, on account of their slender habit and trailing branches. They should be planted in a rich, porous soil, and kept freely watered.

Cts.

ISOLEPSIS JUNCIODES, (ornamental grass,)

Linaria Cymballaria, or Kenilworth Ivy.

Lobelia Erinus Speciosa.

Cts.

15 Sedum Siboldtir,

10 Senecio (or Micania) Scandens 10

Lycopodium Denticulatum, 10 a 25 Verbena Maonetti Coccinea, 10

" C.ESIUM,

" WiLdenowit,

Listmmachia Numularia,
25 Vinca Elegantissima varie-

25
GATA,

15 a 25

\section{CONVOLVOLUS MAURITANICUS, (New)}

A trailing plant, with bright blue fiowers, admirably adapted for vases or hanging baskets, 25 cts. each.

\section{SEDUM CARNEUM-Variegatum,}

A variegated plant of great beauty, also adapted for baskets and vases. From its close compact growth, is also well adapted for edges or ribbon lines for front borders, $25 \mathrm{cts}$. each, $\$ 2$ per doz.

\section{Winter-blooming Bulbs.}

Under this head may be classed two distinct kinds, the hardy sorts which are usually forced into bloom, among which the Hracintu has become, by common consent, the favorite, not only for its exqisite tints, but also for its delightful perfume. They are also grown extensively in glasses with water, and in this form, are an interesting and beautiful object in the Parlor window. For this purpose, we would recommend the following varieties: Red and Pink.-Bouquet Tendre, Panorama, Temple d'Apollon, Mars- White-Anna Maria, Prince of Waterioo, La Deesse, Grand Vainqueur. Blue.-Lord Wellington, A la Mode, Mignonne Von Dryfhout, Prince of Saxe Weimer. Yellow. -Bouquet d'Orange, Croesus, King of Holland. Tulips are also forced into early bloom; for which purpose the double and single Van Thol, double, Rex rubrorum, scarlet; La Candeur, white; Tournesol, yellow and red; Yellow rose, yellow; are the best. These, with a few Jonquils, Crocus, and Narcissus, will make a beautiful display during the 
winter and early spring months. The other class belongs more strictly to the Green-house-being principally natives of warm climates, they require a more careful treatment. The following are the mos: desirable:--Ixia, Sparaxis, Oxalis, Cyclamen, Gladiolus ramosus, and Gladiolus Queen Victoria, for winter blooming, and Amaryllis (several varieties), Achimenes, and Gloxinias, for summer blooming.

For prices and varieties, see Bulb catalogue.

\section{ORNAMENTAL TREES.}

Every one, with any pretensions to taste, admits that trees are beautiful objects; and that they are as useful as they are beautiful, will be granted by all. There is no locality, however desolate, but may be improved by their presence, and no spot, however refined, to which they may not contribute a fresh grace.

\section{List of Ornamental Trees and Shrubs. SELECT EVERGREENS.}

Normay Sprdce. - The most useful, hardiest and most graceful of popular evergreens, 25 cts. to $\$ 200$

Austrian Pine.-A robust and grand evergreen tree,

Hemlock Spruce.-A very delicate and graceful indigenous tree, a little difficult of removal, but when once established, second to none in beauty, 25 cts. to 100 American Arbor Vrte.-Very useful and easy of transplanting,

Siberian Arbor Vita.-A compact vuriety of the American, of very close habit, quite hardy,

Golden Arbor Vite.-A beautiful dwarf variety, 50 cts. to 200

JUNIPER-Irish, very desirable for planting along walks, $50 \mathrm{cts}$. to

. $\quad$ Ericoides, dwarf, beautiful ; suitable for cometery lots,

“ Sabina, dwarf, bushy,

". " " variegata,

“ Swedish,

$50 \mathrm{cts}$. to 100

Box, tree,

25 " 200

" edging, for edging walks and borders, 12 cts. per yard; per 100 yards, $\$ 10.00$

Euonrmus japonica, 25 . “

، variegata,

25 “

Holly Leaved Berberry, (Mahonia.)-A low evergreen with

shining foliage and yellow flowers ................................ .50

RHododendron Ponticum.................................\$1.00 to $\$ 2.00$ 


\section{DECIDUOUS TREES.}

There is such a difference of taste on the subject of Deciduous Or 1 amental and Shade trees, that it is superfluous for us to offer a selection. We have a large stock of all the leading varieties, such as

Maples, several varieties.

Horse Chestnuts,

Poplars,

Elms,

Ash,

European Sycamore,
Linden,

Paulonia Imperialis,

Willows,

Magnolia,

Larch, etc.

\section{FLOWERING SHRUBS.}

These add materially to the beauty of the garden, furnishing a supply of fragrant flowers during spring and summer. 25 to 50 cents each.

Spire, or Bridal Wreath,

Srringa, or Lilac, of sorts.

Calycanthus, or Sweet Shrub.

Prrus Japonica,

Dodble Flowering Almond,

Deutzias, of sorts.

Snow Berry, Mock Orange,
Weigela Rosfa,

Forstrita,

Double Flowering Peach,

Laburnum, or Golden Chain,

Double Chinese Cherry,

Rhus Cotinus (Mist Tree.)

Magnolia,

Chionanthus, a white fringe tree.

The above are only a few select items from a large list of trees and shrubs cultivated by me.

\section{HARDY VINES AND CREEPERS.}

These are desirable for covering Arbors, Trellises, \&c., and add much to the beauty of the garden. 25 cents each.

\section{Virginian Creeper,}

Pipe Vine,

Trumpet Creeper, Clematis Flammula, Carolina Jasmine, IvY, of sorts.
Hop Vine,

White Jasmine,

Yellow Hardy Jasmine,

Honeysuckle, of sorts.

Passion Vine,

Grycine, or Wisteria.

\section{IEW VARIEGATED-LEAVED JAPAN HONEYSUCKLE.}

Lonicera Brachypodium Aurea Reticulata.-This is one of the recent introduetions, the foliage beautifully variegated. Price 75 cents each. 


\section{Hedges.}

A well-kept hedge is one of the greatest ornaments of a country residence. The Osage Orange has been much used as a plant for forming strong outside fences, and when properly cared for will give satisfaction. The Honey Locust is nothing inferior; indeed, it is preferred by those who have made trial of both. It grows freely, although the soil may not be of the best description, and fills out readily from shearing. For inside dividing hedges, the Pyrus Japonica cannot well be excelled, and the box-leaved Privet is also well adapted. Very beautiful hedges can be made with the European beech. Buckthorn is also much used for the same purpose.

Many hardy flowering shrubs may easily be trimmed hedge-fashion, and form beautiful objects when in flower. Weiglea roses, Spireas of various kinds, the Berberries, Hibiscus, \&c., are a few of those most useful in this respect.

For Evergreer hedges, nothing suits better than the American arborvitæ. The Hemlock Spruce is unequalled in its adaptability, and forms perhaps the most beautiful hedge of any. The Cedars and Junipers make good screens. Where a strong and dense hedge is wanted, the Norway Spruce will be found satisfactory. Many plants will grow compact, if cut and trimmed with sufficient care.

\section{Box-Edging,}

Few people, except professed gardeners, know how this handsome border ornament ought to be planted. It is usually stuck in a few inches, and left straggling on top of the ground, with three or four times as much top and three or four times less bottom, than it ought to have. Box grows nearly as well from the branches as the roots. Now the trench in which the edging is to be planted should be a full spade deep on the border side, being a few inches shallower on the alley side -the soil-should be made fine-and the box inserted to the bottom of the trench, packed in tightly with soil, leaving only from one and a half to two and a half inches out of ground. There will be no danger of it not growing, or of producing full foliage at the ground. Of course, no one would think of planting Box without a line.

Trimming box-edging is rarely performed either skilfully or judiciously. Instead of cutting off the top squarely, and below the preceding year's growth, let it be pruned to an angle like the letter A, taking care not to cut below the new growth, and you will, through the whole season, have a beautifully green, thrifty edging.

Having devoted the greater portion of our space to the Flower and ent gardens, we bave but a few words to add on the subject of 


\section{FRUIT CULTURE}

This branch of Horticulture is so extensive and important, that we should be unwilling to attempt to offer any hints calculated to be of service in the brief space that we could appropriate to them. In view of the increased attention latterly given to the cultivation of choice fruits, we are prepared to supply the demand for choice varieties of the leading objects, such as

$\begin{array}{ll}\text { Apples, } & \text { Grapes, } \\ \text { Pears, } & \text { Raspberries, } \\ \text { Cherries, } & \text { Stratberries, } \\ \text { Plums, } & \text { Blackberies. }\end{array}$

And, indeed, every desirable article in the fruit line.

The Native Grape has latterly engrossed a large share of attention, and a greater impulse has been given to its culture by the valur ble accessions which we yearly receive. Those old standard varieties, the Catawba and Isabella, are now mainly superseded by others that ripen earlier, and thus escape the fall frosts, which in many localities injure the crop, more especially the Catawba. The newer varieties are also more generally exempt from mildew, although there are possibly none that are entirely proof against its attacks at particular seasons. In flavor and quality of fruit the improvements are more marked, and in the Delaware and Rebecca we have a near approach, in this respect, to some of the famed foreign varieties. The following are considered the hardiest and best :

$\begin{array}{lll}\text { Isabelia, black. } & \text { Rebecca, white. } & \text { Delaware, red. } \\ \text { Catawda, red. } & \text { Concord, black. } & \text { Diana, red. } \\ \text { Maxatawner, white. } & \text { Creveling, purple. } & \end{array}$

Maxatawney, white. Creveling, purple.

\section{THE STPAWBERRY.}

The circumstances of soil and climate greatly influence the varieties of this fruit, both in its productiveness and quality; hence the wide difference of opinion upon their respective merits. Fortunately there are varieties enough to suit all soils and tastes, and each cultivator can, by careful experiment, discover which of the most popular varieties are suited to his circumstances.

The Strawberry gives most satisfaction when planted in a wellworked, deep loamy soil, and the best crops can only be raised by a strict adherence to clean culture; particularly should every runner be picked off as soon as it makes its appearance, and no weeds allowed to interfere with the growth of the plants. Each plant should also be kept distinct; indeed, with many of the newest strong leafing sorts, 
distinct culture is indispensable, otherwise they will speedily corer the whole ground with a mass of foliage and runners, and produce little if any fruit. Beds for propagating should be planted solely for that purpose. Mulching during summer when the fruit is ripening, will assist greatly towards a heary continuous crop, and a sprinkling of litter should be thrown orer them about the middle of December, to protect the buds during winter.

Among the most prolific of all Strawberries, is Wilson's Albany Seedling, and among foreign varieties, the Triomphe de Gand is the best for general purposes. Douner's Prolific is a good fruit, and a most robust grower. The finest flarored is, perhaps, Ticomptesse Hericaurt de Thury, the Hooker and Fillmore are also excellent varieties. Hovey's Seedling is still a great farorite with many, and for earliness, size, color, flaror and productireness none can excel the new variety introduced into notice by us last fall, called

\section{FRENCH'S SEEDLING.}

This rariety originated on the grounds of Mr. French, near Moorestomn, X. J., and the fruit was introduced into our market last season, commanding the highest price, and attracting unirersal attention, for its beautiful bright scarlet color, form, and excellent qualities.

Price of plants, $\$ 1.50$ per dozen; $\$ 8.00$ per hundred.

\section{THE RASPBERRY.}

Owing to the fact that the winters, more or less, injure all Raspberry plants, and many of the best sorts are much cut by the frosts, the Raspberry has not been so extensirely cultirated as its importance demands. Laying down the canes and corering them lightly with soil, is the most preralent, as it is the most simple and efficient method of protection. This is, howerer, attended with considerable trouble; and through neglect such choice and tender rarieties as the Orange, Fastolfi, Franconia, Hornet, and others, fail producing a crop. We have, however, at length the pleasure of offering a Raspberry which combines with great productireness extreme hardiness. Is also of good size and excellent flaror, and haring originated near this city, it has been named the

\section{"PHILADELPHIA RASPBERRY."}

We have tested this variety thoroughly in our own nursery grounds, and unhesitatingly endorse the character giren to it by Mr. Parry (an extensive fruit grower near this city,) who states_" Haring had the severe test of ten years' practical trial, side by side with all the leading rarieties, the conclusion arrired at is, that it is the largest, most productive, and best hardy Raspberry in the world."

We will furnish a limited quantity of plants, at the following rates: $\$ 2.50$ per dozen; $\$ 15$ per hundred. 


\section{THE FARMERS AND GARDENER'S LIBRARY.}

At the request of many of our friends, we publish a list of the leading works on Agriculture, Horticulture and Rural affairs. When ordered by mail, 10 to 25 cents must be added to cost of book, to prepay postage.

American Farmer's Encyclopædia................................... \$5 00

American Weeds and Useful Plants................................ 150

Allen's Stable Book..................................................... 125

Allen's (R.L.) American Farm Book................................ 125

Allen's (R.L.) Diseases of Domestic Animals........................ 100

Allen's (L.F.) Rural Architecture................................... 125

Allen (J. Fisk) on the Culture of the Grape.................... 100

Barry's Fruit Garden................................................. 150

Bement's (C.N.) Rabbit Fancier....................................... 25

Blake's (Rev. John L.) Farmer at Home........................... 150

Browne's American Bird Fancier.................................... 25

Browne's Poultry Yard............................................... 125

Browne's Field Book of Manures.................................... 125

Breck's Book of Flowers............................................... 125

Brid'geman's Florist Guide........................................... $\quad 50$

،. Kitchen Gardener......................................... 60

،. Young Gardener Assistant............................. 150

Buist's American Flower Garden Directory........................ 125

“ Family Kitchen Gardener.................................... 75

“ Rose Manual.................................................... 75

Chorlton's (William) Grape Growers' Guide......................... $\quad 75$

Cobbett's American Gardener........................................... $\quad 60$

Cole's (S. W.) American Fruit Book................................ $\quad 60$

" American Veterinarian........................................... 60

Copeland's Country Life .............................................. 250

Coulter's Principles of Botany..................................... 50

Domestic and Ornamental Poultry, (plain plates).................. 125

Downing's (A.J.) Landscape Gardening, (out of print) ............ 350

“ Fruit and Fruit Trees of America, (revised edition)... 200

"، Country Houses................................................. 450

"Ladies Companion to the Flower Garden................ 150

Dadd's American Cattle Doctor........................................ 125

، Modern Horse Doctor........................................... 125

“ Anatomy and Physiology of the Horse.................... 250

Eastwood (B.) on the Cultivation of the Cranberry................. 60

Elliott's (F.R.) Western Fruit Book................................. 125

Every Lady her own Flower-Gardener............................... 25 
French's Farm Drainage........................................... 125

Fessenden's (T.G.) American Kitchen Gardener..................... 25

“ Complete Farmer and Gardener........................ 125

Field's Pear Culture.................................................. 125

Fish Culture.................................................... 125

Flint on Grasses...................................................... 125

Guenon, Teatise on Milch Cows....................................... 75

Grape Culture and the Strawberry................................. 75

Hooper's Dog and Gun....................................................... 25

،. Western Fruit Book......................................... 125

Johnston's Agricultural Chemistry and Geology.................... 125

Kern's Practical Landscape Gardening............................ 200

Kemp on Landscape Gardening..................................... 200

Lindsay's Horticulture (Downing)................................. 100

Langstroth on the Hive and Honey Bee.......................... 125

Leuchar's how to Build and Ventilate Hot-Houses.................. 125

Liebig's (Justus) Familiar Science of Chemistry................... 75

Meehan's Ornamental Trees................................................ 75

Mahan's American Gardening..................................... 3.00

Milburn on the Cow and Dairy Husbandry.......................... . 25

Miles on the Horse's Foot and how to keep it Sound................ 25

Munn's (B.) Practical Land Drainer.................................. 50

Nash's (J.A.) Progressive Farmer..................................... 75

Neill's Fruit, Flower, and Vegetable Gardener's Companion...... 125

Olcott's Sorgho and Imphee, the Chinese and African Sugar Canes. 160

Pardees Strawberry Culture............................................ 75

Pedder's Farmer's Land Measurer.................................... 50

Popular History of British Ferns................................. 250

Parson's History and Cultnre of the Rose.......................... 125

Produce and Ready Reckoner........................................... 60

Phin's Grape Culture and Wine Making......................... 125

Pairlor Gardener.................................................................... 75

Quimby's Mysteries of Bee Keeping.............................. 125

Rand's Flowers for the Parlor and Garden......................... 250

Randall's Fine Wool Sheep Husbandry.............................. is

Remelin's (Charles) Vine-Dresser's Manual....................25 and 50

River's Orchard House.................................................. 50

Richardson on the Honey Bee..................................... 25

Smith's Landseape Gardening, Park and Pleasure Grounds....... 125

Saxton's Rural Hand Books............................................ 150

Thomas' American Fruit Culturist................................... 125

“ . Farm Implements............................................... 125

Turner's (J.A.) Cotton Planter's Manual........................... 125 
Village and Farm Cottages........................................... 200

Villas and Cottages................................................. 250

Warder's (J.A.) Hedges and Evergreens........................... 100

Week's Manual on Bees.................................................. 25

Youatt and Spooner on the Horse................................... 150

Youatt, Breeds and Management of Sheep......................... 100

"6 : and Martin on Cattle.......................................... 150

\section{HORTICULTURAL IMPLEMENTS.}

Averancator or Tree pruning Shears, for poles, from $\$ 3.00$ to $\$ 6.00$ " " " small sizes, " " 2.00 to 2.50

Large size " $\quad$ " sliding cut, " $\quad 6.00$ to 7.50

Hedge or Box Shears, .................................... 2. 2.00 to 3.00

Lawn " with two wheels,................ 4.50

Grass Border " plain................................. 3.50 to 5.00

" " " with wheel....................... 5.00 to 6.00

Ladies garden or box shears...............................

Hand pruning Shears, serviceable for pruning Fruit

Trees, Grape-Vines, \&c..........

4. 4 a with sliding cut..................

Vine Scissors, for thinning out Grapes,

Grass Edging Knives, for paring the edges of grass..

Flower Scissors or Gatherers, for cutting and holding the flowers.....

Pruning Scissors, Bow handles.

2.00

2.00 to 3.00

1.50 to 2.00

1.00 to 1.50

75 to 1.50

2.50

1.00 to 1.50

50 to 1.50

Grafting

" Knives, Saynor's various patterns

1.50
75

Budding "Saynor's various patterns.............. 66 "Turners, \&c.

66

1.50

1.00 to

1.25

Pruning and Budding Knives, in sets in mcrocco cases, Pruning Saws, from 14 to 20 inches.

75 to

4.50 to

5.00

Grafting Saws.

75 to 1.50

1.00

Pruning Saws, with sockets for long handles............. $\quad 2.00$

Garden Rakes, wrought iron.................................

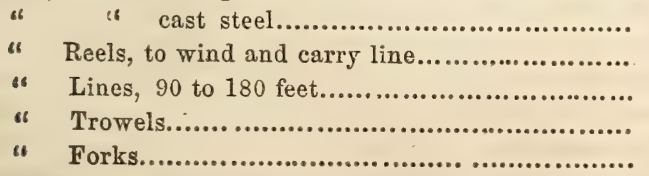

50 to 1.00

75 to 1.50

85 to 1.50

50 to 1.00

35 to 1.75

25 to $\quad 75$

English Lawn Rakes, from.............................. $\quad 3.00$ to $\quad 5.00$ 
8

Patent rivet back Lawn Scythes

1.50 to

2.50

s

“6

16 Grass Hooks.

75 to

1.00

Spading, or Garden Forks

1.25 to

3. 50

Watering Iots, from

1.00 to

2.00

Garden Hows, Cast Steel, all sizes.

40 to 1.00

Ladies and children Garden Tools in sets.

1.00 to

5.00

Green-house syringes of brass

6.00 to 10.00

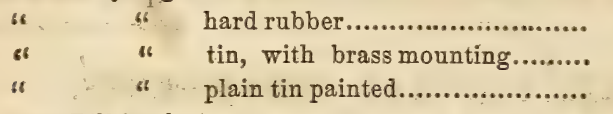

4.00

4.50

1.25

Briar and Bill hooks.

75 to

\section{WHAIE OIL SOAP.}

An effectual remedy for destroying Insects on Plants, Trees, Vines, etc.

FOR WASHING DOWN THE BARK OF TREES, GRAPE-VINES, \&c.-Take a quarter of a pound of the Soap, four pounds Sulphur, a quarter of a pound of Tobacco, one ounce Nux Vomica; pour over these three gallons boiling water, stir until thoroughly mixed; when cool apply with a brush.

FOR DESTROYING THE APHIS OR PLANT LOUSE, SLUGS ON ROSES, THRIPS ON GRAPE-VINES, MLDEW, SLUGS ON PEARTREES.-Take a qnarter of a pound of the soap, dissolve thoroughly with boiling water, add in all two gallons of water, strain through a sieve or cloth, apply with a syringe or the rose of a watering pot to the plants. The best time to apply the preparation is in the evening, or quite early in the morning. 


\section{COM M MENDATORY.}

Office of Asst. Com. Genl. Subsi

New York, December 9, 1863. ,

Please inform me if you can supply all the seeds required for the climate of New Mexico. Your seeds have done so well heretofore, I am inclined to take from you again.

Col. A. B. Eaton.

Muscatine, Iowa, April 30, 1863.

The box of plants arrived yesterday in the very bust condition, not even a wilted leaf among them. My friends are perfectly satisfied with them. I shall not only order all my flowers fom your establishment, but also my vegetables.

Sarah Brannan.

Lecompton, Kansas, June 9, 1863.

All the seeds received from you this spring are first rate, true to name, and doing well.

WM. Leamer.

Binghamton, N. Y., March 16, 1863.

The seeds received from you were satisfactory. The flowers from "Dreer's Pansy" seed, were splendid. I had them at our Fair on exhibition, for which I was awarded the highest premium.

D. F. HoLme,

Salineville, Ohio, April 20, 1863.

The paper of your "Verbena Seed" produced fifteen varieties.

Mrs. S. C. Bracker.

Fowlerville, N. Y., Sept 21, 1863.

The Double Zinnia, Phlox Drummondii, and Cockscombs, from your seeds, surpassed in richness of color and size any that $I$ have ever seen at Floral exhibitions in England.

WM. Rowe.

Amsterdam, N. Y., November 13, 1863.

The plants arrived safely, beautifully packed, and in fine condition. I am well pleased with the assortment. MrS. S. SANFord.

Sparta, Michigan, April 30, 1863.

Please accept my thanks for the excellent order in which my plants were received.

L. E. Leavitit.

Laporte, Indiana, April 22, 1863.

My plants aryived in perfect order, and gave entire satisfaction. To show my approbation of the generous manner in which my order was filled. I herewith send another.

Mrs. B. P. WALKer.

North Branch, Penna., April 18, 1863.

My plants arrived fresh as when packed-could have been sent to California in good condition.

Mary A. Cox.

The box of plants came in good order, and are very fine.

Buffulo, N. Y., April 25, 1863.

A. P. Thompson.

Cleveland, Ohio, November 12, 1863.

All the plants you sent came in fine order, and are as good? av ever had.

GEO. A. S 
1864.

\begin{tabular}{|c|c|c|c|c|c|c|c|c|c|c|c|c|c|c|c|c|c|c|c|c|}
\hline \multicolumn{7}{|c|}{ JANUARY. } & \multicolumn{7}{|c|}{ MAY. } & \multicolumn{7}{|c|}{ SEPTEMBER. } \\
\hline & $\underline{M}$ & Tu & W & $\underline{T h}$ & Ex & Sa & $\underline{\mathrm{Su}}$ & $\underline{\underline{M}}$ & Tu & $\underline{w}$ & Th & $\underline{F r}$ & Sa & u & $\underline{M}$ & Tu & $\underline{w}$ & Th & Fr & 88 \\
\hline & & & & & & 2 & 1 & 2 & 3 & 4 & 5 & 6 & & & & & & 1 & 2 & \\
\hline 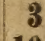 & 4 & 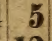 & 6 & 1 & ? & $\Rightarrow$ & 9 & 9 & 10 & 11 & 12 & 13 & 14 & 4 & 5 & 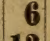 & 7 & 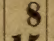 & & \\
\hline & 11 & 1 & 13 & & . & 16 & ) & 16 & 17 & 18 & ? & 20 & 21 & 1 & 12 & 13 & 14 & 15 & 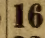 & 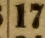 \\
\hline & 18 & & & 2 & & 23 & & 2 & & 25 & 2 & 27 & 28 & & 19 & & & & & \\
\hline & 25 & & 2 & 2 & & 30 & & 30 & 31 & &. & $\because$ & $\cdots$ & & & 7 & 8 & 9 & & \\
\hline & & & & & & & & & & & & & & & & & & & & \\
\hline \multicolumn{7}{|c|}{ FEBRUARY. } & \multicolumn{7}{|c|}{ JUNE. } & \multicolumn{7}{|c|}{ OCTOBER. } \\
\hline & $\underline{M}$ & Tu & $\underline{W}$ & Th & Fr & Sa & Su & $\underline{M}$ & Tu & $\underline{w}$ & Th & Fr & Sa & Su & $\underline{M}$ & Tu & W: & $\mathrm{Th}$ & Fr & Sa \\
\hline & 1 & 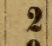 & 3 & : & 5 & 6 & & & & 1 & 2 & 3 & 4 & & & & & & & \\
\hline 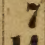 & 8 & 9 & 10 & 11 & 12 & 13 & 5 & 6 & 7 & 8 & 9 & 10 & 11 & 2 & 3 & 4 & 5 & & $\therefore$ & \\
\hline 4 & 15 & 16 & 17 & 1 & 1 & 20 & 12 & 13 & 14 & 15 & 16 & 17 & 1 & 9 & 10 & 11 & 2 & & 14 & 10 \\
\hline & 22 & & 94 & & & 27 & & 20 & 21 & 2 & & 24 & 25 & 16 & 17 & & & & & 12 \\
\hline & 29 & & & & & . & & 27 & 2 & 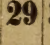 & 30 . & & & & & & & & i & 3 \\
\hline & & & & & & & & & & & & & & & & & & & & \\
\hline \multicolumn{7}{|c|}{ MARCH. } & \multicolumn{7}{|c|}{ JUIY. } & \multicolumn{7}{|c|}{ NOVEMBER. } \\
\hline & $\underline{\mathbf{M}}$ & Tu & $\underline{w}$ & $\mathrm{Th}$ & $\underline{\mathbf{F r}}$ & $\mathrm{Sa}$ & Su & $\underline{\mathbf{M}}$ & Tu & $\underline{\mathrm{w}}$ & Th & $\underline{\mathbf{F r}}$ & Sa & $\underline{u}$ & M & Tu & W & Th & Fr & Sa \\
\hline & & & 2 & 3 & 4 & 5 & & & & & & 1 & 2 & & & 1 & 2 & 3 & 4 & $=$ \\
\hline & 7 & 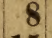 & 9 & 10 & 11 & 12 & 3 & 4 & 5 & & 7 & 8 & 1 & 6 & 7 & 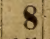 & 9 & 10 & 11 & 12 \\
\hline & 14 & & 16 & 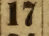 & 18 & 19 & & 11 & 12 & 3 & 14 & 15 & 16 & 3 & 14 & & 6 & & 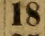 & 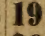 \\
\hline & 21 & & & & 10 & 26 & & 18 & 1 & & & & 2 & & & & & & & \\
\hline & 0 & & & & & & & 2 & & & & & 2 & & & & & & & \\
\hline & & & & & & & & & & & & & & & & & & & & \\
\hline \multicolumn{7}{|c|}{ APRIL. } & \multicolumn{7}{|c|}{ AUGUST. } & \multicolumn{7}{|c|}{ DECEMBER. } \\
\hline & II & Tu & $\underline{w}$ & Th & Fr & $\underline{\mathrm{Sa}}$ & 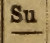 & $\underline{M}$ & Tu & $\underline{\mathbf{w}}$ & Th & Fr & Sa & $\underline{\text { Su }}$ & $\underline{M}$ & Tu & $w$ & Th & Fr & Sa \\
\hline & & & & & 1 & 9 & & 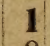 & 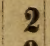 & & 4 & 0 & & & & & & 1 & & \\
\hline & 4 & & & & 8 & 9 & & 8 & 9 & 10 & 11 & 12 & 13 & 4 & 5 & 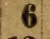 & 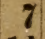 & 8 & & 10 \\
\hline & 11 & 12 & 13 & 1 & 15 & 16 & & 15 & & 17 & 18 & 19 & 20 & 1 & 2 & & 14 & 15 & & \\
\hline & 18 & & 20 & & 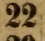 & 23 & & & & 10 & 25 & 26 & 2 & & & & & & & \\
\hline & 25 & & & & & & & & & & & & & & & & & & to & \\
\hline & & & & & & & & & & & & & & & & & & & & \\
\hline
\end{tabular}

ISSUED FROM THE

Horticultural and Seed Warehouse, No. 714 Chestnut Street, PHILADELPHIA: 

permalifeo $\mathrm{pH} 8.5$ 